WSRC-RP-2003-00276

Department of Energy Office of Science and Technology

\title{
Technical Assistance to Kansas City Plant: Mitigation of Polychlorinated Biphenyl Discharges
}

\author{
Kansas City, Missouri
}

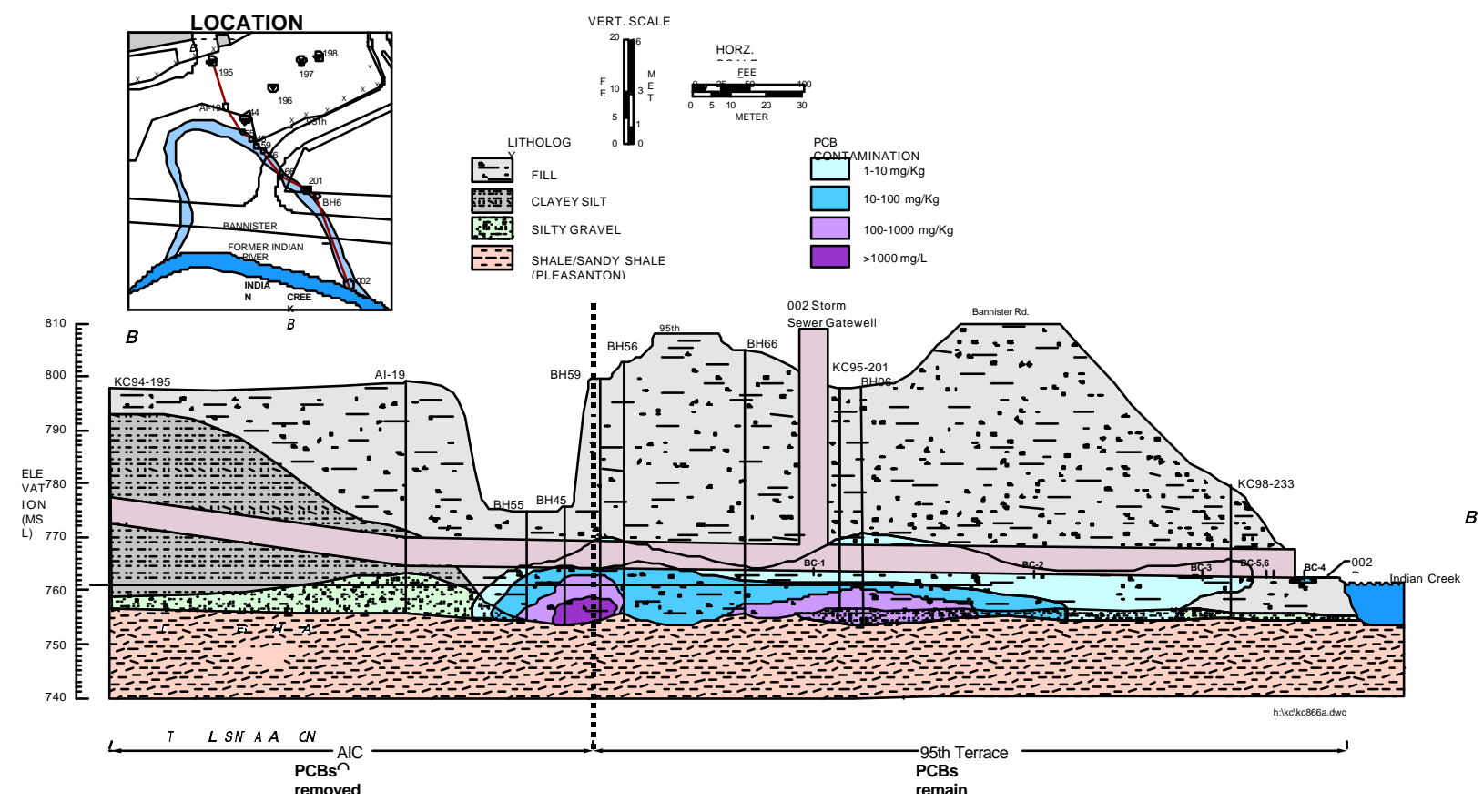

January 28-30, 2003

FINAL REPORT 
This document was prepared in conjunction with work accomplished under Contract No. DE-AC09-96SR18500 with the U. S. Department of Energy.

\section{DISCLAIMER}

This report was prepared as an account of work sponsored by an agency of the United States Government. Neither the United States Government nor any agency thereof, nor any of their employees, makes any warranty, express or implied, or assumes any legal liability or responsibility for the accuracy, completeness, or usefulness of any information, apparatus, product or process disclosed, or represents that its use would not infringe privately owned rights. Reference herein to any specific commercial product, process or service by trade name, trademark, manufacturer, or otherwise does not necessarily constitute or imply its endorsement, recommendation, or favoring by the United States Government or any agency thereof. The views and opinions of authors expressed herein do not necessarily state or reflect those of the United States Government or any agency thereof.

This report has been reproduced directly from the best available copy.

Available for sale to the public, in paper, from: U.S. Department of Commerce, National Technical Information Service, 5285 Port Royal Road, Springfield, VA 22161, phone: (800) 553-6847, fax: (703) 605-6900

email: orders@ntis.fedworld.gov

online ordering: http://www.ntis.gov/help/index.asp

Available electronically at http://www.osti.gov/bridge

Available for a processing fee to U.S. Department of Energy and its contractors, in paper, from: U.S. Department of Energy, Office of Scientific and Technical Information, P.O. Box 62, Oak Ridge, TN 37831-0062,

phone: (865)576-8401,

fax: (865)576-5728

email: $\underline{\text { reports@ adonis.osti.gov }}$ 
WSRC-RP-2003-00276

Department of Energy Office of Science and Technology

\section{Technical Assistance to Kansas City Plant: Mitigation of Polychlorinated Biphenyl Discharges}

Kansas City, Missouri, January 28-30, 2003

Technical Assistance Team / Authors:

Brian B. Looney, Savannah River Technology Center (chair)

Terry C. Hazen, Lawrence Berkeley National Laboratory

David L. Eaton, Idaho National Environment and Engineering Laboratory

Emily Charoglu Boerner, Enviroissues (facilitator) 
WSRC-RP-2003-00276

page ii of $x$

\{"blank"\} 
WSRC-RP-2003-00276

page iii of $x$

\section{EXECUTIVE SUMMARY}

Soil and storm water discharges from the Department of Energy (DOE) Kansas City Plant (KCP) contain polychlorinated biphenyls (PCBs) resulting from past spills and discharges. $\mathrm{KCP}$ has implemented a range of actions to mitigate the soil contamination and to reduce the measured PCB releases. These actions were permitted and overseen by environmental regulatory agencies and included: soil removal, lining and cleaning drainpipes, rerouting water, and the like. Recently, the target outfall discharge limits were lowered and additional actions to isolate and protect the storm sewer are being implemented. DOE KCP requested an independent assessment of the historical and planned activities, identification of additional short-term activities that might further reduce outfall concentrations, and identification of long-term strategies to minimize risks from past PCB spills. The independent technical assistance team (Appendix A) was assembled and completed the requested tasks.

The technical assistance team was impressed with the scientific quality of PCB related studies and support efforts performed by the site contractor, $\mathrm{KCP}$, and their collaborators over the past twenty years. These activities, and the resulting practical outcome-oriented responses, have significantly decreased PCB concentrations in Outfall 002. The team identified several notable technical items. The team was encouraged by the information provided and the site's progress in addressing PCBs in the outfall. We did identify a variety of potential opportunities and have described these and provided a summary description and a preliminary evaluation of each. We would encourage KCP to incorporate these opportunities, as appropriate, into their plans. In particular, the team was concerned with extended continuation of the existing response concept of "isolating the storm drain system from the residual PCBs" and with viewing such actions as a final protective actions. While this approach has generated good PCB reductions in stormwater discharges in the past, simple isolation is unlikely to provide the type of robust and multi-layered protection desired by facility managers/administrators and by regulators and stakeholders. The team felt that the next phase of storm drain isolation and reconfiguration activities - those activities that are currently being planned in cooperation with regulators - are generally appropriate. Importantly, the team believes that the most significant PCB reductions are likely to have already been made or will result from these next activities and that significant outfall concentration reduction from future rounds of "storm drain isolation" are unlikely. Instead, we recommend that the site move toward medium-term actions that diversify protection to the storm drain system and long-term actions that consider isolation, destruction or removal of primary PCB sources in the soil and within facilities.

The team identified a few critical and unresolved issues. These included: need for a clear definition of closure and a strategy for transitioning to long-term operation of the facility as a "brownfield", role of various uncertainties and conservatism in setting standards, challenges of site specific geological limitations such as low permeability, and issues of schedule, budget and lifecycle costs. The existing KCP ER Strategy Document (Appendix B) provides a good base for resolving these issues - with additional detail 
WSRC-RP-2003-00276

page iv of $x$

KCP could develop clear strategies that provide a comprehensive and thorough basis for closure and transitioning to long-term operation.

\section{Short-term responses supported....}

The team evaluated the past and planned storm drain isolation efforts. In particular, we support all of the short-term activities in the draft Settlement Agreement as potentially useful. The team discussed additional actions. The following ideas were considered of merit by the team and may be useful to integrate into the planned KCP Settlement Agreement actions: composite and comparative sampling, expand utilization of semipermeable membrane sampler, reroute and reuse single pass cooling water, increase utilization of scientific support study results, remove or treat sediment, eliminate nonstorm water sources to outfall, renegotiate compliance standards, and analyze chromatogram patterns periodically for evidence of attenuation. A detailed discussion of each of these topics is provided to assist KCP. Where innovative or alternative methods are proposed (e.g., recent advances in analytical methods, composite sampling, etc.), references to prior use are provided. Several of the suggestions were low cost but may provide immediate benefits. One example is addition of granular activated carbon (or other appropriate hydrophobic sorbent) to the sediment traps in the storm sewer system to minimize PCB contributions from periodically accumulated solids. The carbon would be removed and replenished along with trapped sediments according to the current maintenance schedule.

\section{Medium-term Actions Recommended...}

Past and present storm sewer protection and isolation efforts can be supplemented by a medium-term activity to attenuate the low concentrations of PCBs that bypass the protections and enter the storm sewer. Such an effort would add an additional layer of protection. By diversifying the response, the overall system can be made more robust and PCB fluxes can be more reliably reduced and stabilized. All of the proposed options would require creative and careful engineering to overcome site-specific challenges such as large storm surges and changes in water elevation in Indian Creek. All of the supplemental medium-term actions discussed by the team involve PCB attenuation in the base flow using filtration, sorption, settling and similar techniques. Large storm surges and any reverse flows from Indian Creek during storms would generally contain few PCBs and could be handled by appropriate bypass systems. The team felt that three possible systems might be viable. These were: (1) a wetland treatment cell, (2) trench based treatment, and (3) a small standard package treatment plant. A variant of this strategy that uses the existing surge basin may represent a relatively low cost option. All of the medium-term options require modifications to include a lift station to deliver water, an attenuation cell or treatment unit, a system to return water to the storm sewer, and a system to handle storm events and high water. Most of the medium-term options require an analysis to make sure that any increased infiltration does not adversely impact nearby levees or any existing soil contamination. The team felt that opportunistic lowcost implementation of a medium-term option will provide benefit in reducing and stabilizing PCBs in Outfall 002. 
WSRC-RP-2003-00276

page $\mathrm{v}$ of $\mathrm{x}$

\section{Long-Term Strategies Should be Considered....}

Efforts to decrease releases of PCBs to levels that are "as low as reasonably achievable" and to minimize exceedances of sub $\mu \mathrm{g} / \mathrm{L}$ targets may require efforts to directly address the sources within facilities and in the soil. PCBs within facilities are addressed using standard operational controls, isolation methods (epoxy coatings and the like), and surface decontamination methods. Addressing high strength PCB wastes that have already been released into the soil is a significant challenge and will require additional data and careful planning - the team has generated a technology matrix that identifies key issues and uncertainties to assist KCP in this challenging stage. Some of the technologies are not well matched to the KCP site, due to the low permeability for example. Some technologies may not provide sufficient benefit to justify their cost or may in fact cause collateral damages to the environment that offset their benefits. The discussion is organized according the classes of actions that can be used to address high strength PCBs in soil: (1) institutional control and monitored natural attenuation, (2) destruction methods, (3) immobilization and isolation methods and (4) enhanced removal methods. Following the discussion, the team separated the technologies into viability categories "may be viable at KCP", "limited viability may be useful in combination with other strategies", and "not recommended". It is important to note that the PCB sources in soil at the KCP site represent a complex and significant challenge. The team identified substantial caveats and limitations for all of the technologies - even those in the "may be viable" category. The discussion of long-term options presumes that appropriate and complementary short-term and medium-term activities are also performed. We would encourage KCP to read the descriptions and caveats in the body of the report and to perform additional evaluation to determine if the technologies might actually be applicable. The various long-term technologies are listed below.

May Be Viable at KCP
\begin{tabular}{|l|l|}
\hline Strategy or Technology & Major concerns \\
\hline Institutional Control & $\begin{array}{l}\text { Leaves high concentration PCB sources in } \\
\text { place }\end{array}$ \\
\hline $\begin{array}{l}\text { Bioremediation (liquid) - primarily in an } \\
\text { infiltration gallery implementation over a long } \\
\text { period }\end{array}$ & $\begin{array}{l}\text { May be difficult or infeasible to deliver } \\
\text { nutrients throughout system }\end{array}$ \\
\hline $\begin{array}{l}\text { Hydraulic Controls - primarily in an } \\
\text { upgradient geosiphon implementation }\end{array}$ & $\begin{array}{l}\text { Leaves high concentration PCB sources in } \\
\text { place, changes flow patterns }\end{array}$ \\
\hline
\end{tabular}


WSRC-RP-2003-00276

page vi of $x$

Limited Viability but May Be Useful in Combination with Other Strategies

\begin{tabular}{|c|c|}
\hline Strategy or Technology & Major concerns \\
\hline Bioremediation (gas) & $\begin{array}{l}\text { May be difficult or infeasible to deliver } \\
\text { nutrients throughout system, active system }\end{array}$ \\
\hline Chemical oxidation & $\begin{array}{l}\text { May be difficult or infeasible to deliver oxidant } \\
\text { throughout system, oxidant half life precludes } \\
\text { slow long-term delivery }\end{array}$ \\
\hline Free product removal & $\begin{array}{l}\text { Difficult to find, large residual, most sources } \\
\text { do not reliably produce free product (use } \\
\text { opportunistically) }\end{array}$ \\
\hline Sheet pile wall & Cultural interferences \\
\hline Electrochemical destruction & $\begin{array}{l}\text { Not ready for use at this time and may be } \\
\text { difficult to implement with KCP interferences. } \\
\text { But somewhat applicable to clayey soils and } \\
\text { progress of research should be monitored to } \\
\text { determine future viability. }\end{array}$ \\
\hline Excavation & $\begin{array}{l}\text { Expensive and poses high risk to workers and } \\
\text { the environment in this setting. May have } \\
\text { limited use for small, shallow and accessible } \\
\text { sources. }\end{array}$ \\
\hline Thermal Removal (steam and six-phase) & $\begin{array}{l}\text { Risk due to mobilizing high strength sources - } \\
\text { may be difficult to capture mobilized PCBs in } \\
\text { low permeability sediment }\end{array}$ \\
\hline
\end{tabular}

Not Recommended for $\mathrm{KCP}$

\begin{tabular}{|l|l|}
\hline Strategy or Technology & Major concerns \\
\hline Monitored Natural Attenuation & $\begin{array}{l}\text { PCBs are stable and suggestion that they are } \\
\text { substantively attenuating is not technically } \\
\text { justified. Similar to institutional control but } \\
\text { implies additional mechanisms that are not } \\
\text { justified }\end{array}$ \\
\hline Chemical Reduction & $\begin{array}{l}\text { Unsuitable chemistry for } \text { in situ applications } \\
\text { and immature technology }\end{array}$ \\
\hline In situ vitrification destruction & $\begin{array}{l}\text { Expensive and poses high risk to workers and } \\
\text { the environment in this setting }\end{array}$ \\
\hline Freeze barriers & $\begin{array}{l}\text { Effective in short-term but not on time scale of } \\
\text { PCB source stability }\end{array}$ \\
\hline Injected barriers & $\begin{array}{l}\text { Difficult in low permeability - difficult to } \\
\text { generate quality and reliability required }\end{array}$ \\
\hline Permeable barriers & $\begin{array}{l}\text { Not suited to low permeability and for PCBs } \\
\text { (contaminant not delivered to barrier during } \\
\text { it's active lifetime) }\end{array}$ \\
\hline $\begin{array}{l}\text { Chemical Extraction (surfactants and } \\
\text { cosolvents) }\end{array}$ & $\begin{array}{l}\text { Difficult in low permeability - high residuals } \\
\text { likely, risk of mobilizing high strength sources }\end{array}$ \\
\hline
\end{tabular}


WSRC-RP-2003-00276

page vii of $\mathrm{x}$

$\mathrm{KCP}$ faces a challenging and complex task - comprehensively addressing the historical PCB contamination at their facility. The technical assistance team encourages selection and implementation of technologies using a comprehensive lifecycle mindset and we hope that the information provided in the report assists in meeting the objective of providing a high level of responsible environmental stewardship. 
WSRC-RP-2003-00276

page viii of $x$

\{"blank"\} 
WSRC-RP-2003-00276

page ix of $x$

\section{Table of Contents}

Department of Energy Office of Science and Technology

Technical Assistance to Kansas City Plant: Mitigation of Polychlorinated Biphenyl

Discharges, Kansas City, Missouri, January 28-30, 2003

EXECUTIVE SUMMARY

.iii

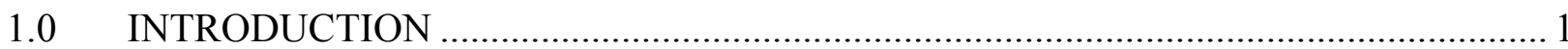

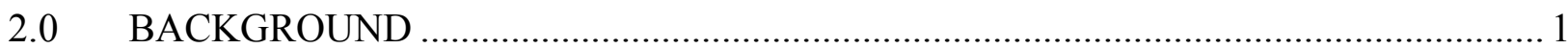

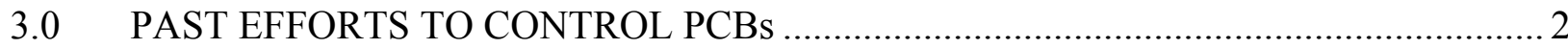

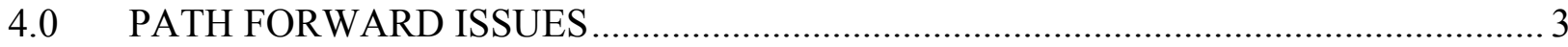

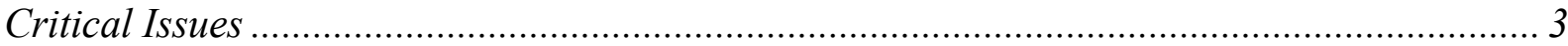

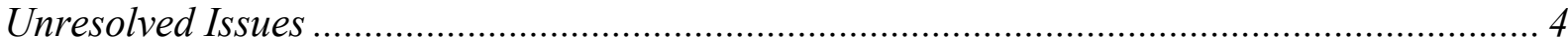

$5.0 \quad$ PATH FORWARD RECOMMENDATIONS ...................................................... 5

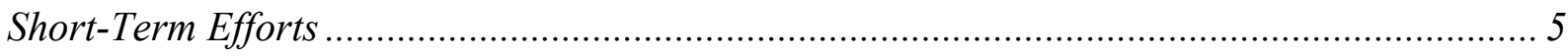

Settlement Agreement Corrective Actions ............................................................... 5

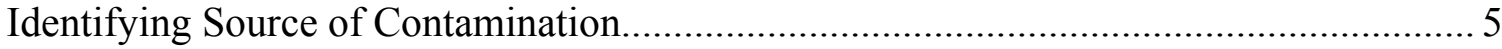

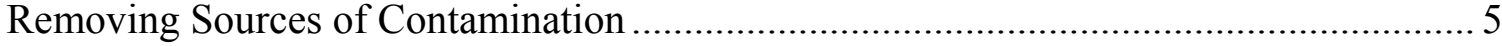

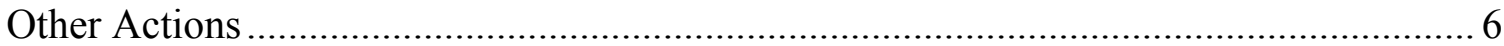

Additional Recommendations for Settlement Agreement ............................................. 6

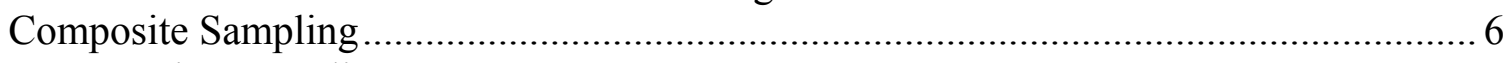

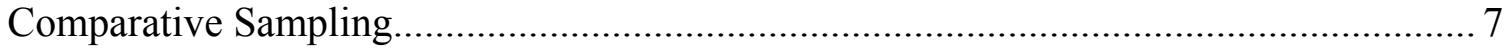

Utilization of Semi-Permeable Membrane …......................................................... 7

Rerouting of Single Pass Cooling Water ........................................................................ 7

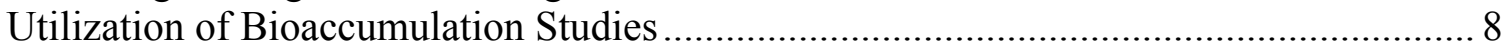

Sediment Removal or Treatment ..................................................................... 8

Eliminate All Non-Storm Water Sources to Outfall ..................................................... 8

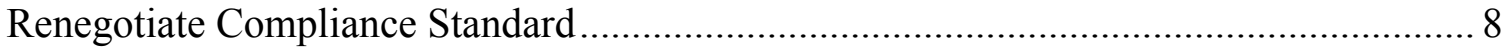

Periodic Chromatographic Analysis .................................................................... 9

Medium-Term Efforts to Reduce PCBs at the 002 Outfall ...................................................... 9 
WSRC-RP-2003-00276

page $\mathrm{x}$ of $\mathrm{x}$

Long-Term Strategies (Source Control) .................................................................... 11

Institutional Control and Monitored Natural Attenuation ............................................. 11

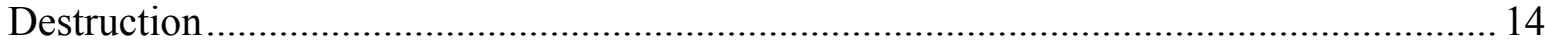

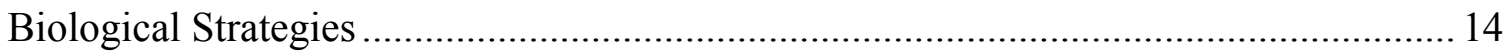

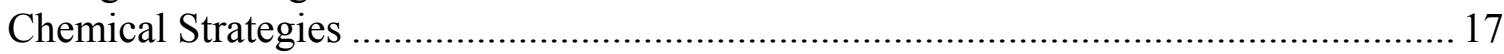

Isolation/Immobilization..................................................................................... 24

Sheet Pile and Other Engineered Walls and Caps .................................................... 24

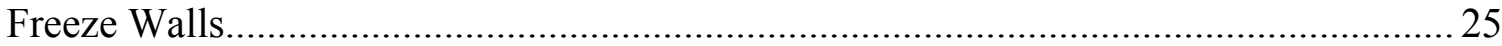

Hydraulic Barriers and Hydraulic Controls ................................................................ 26

Grout and Injected Colloidal Silica Barriers.......................................................... 27

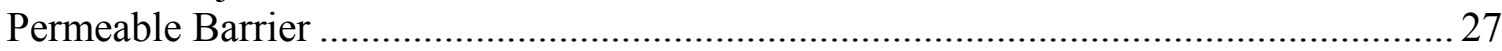

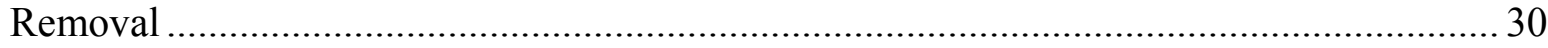

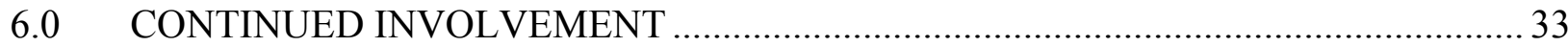

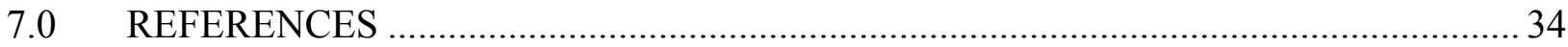

\section{LIST OF APPENDICIES}
A Members of the Technical Assistance Team
B KCP ER Remediation Strategy Document - 2002
C Delaware Estuary Alert
D List of Laboratories
E One Example of a Modular Wetland Treatment System 
WSRC-RP-2003-00276

page 1 of 53

\subsection{INTRODUCTION}

In early 2003, the Department of Energy's (DOE's) Kansas City Plant (KCP) requested technical assistance from DOE's Office of Science and Technology to support efforts to control levels of polychlorinated biphenyls (PCBs) in soils and runoff from past spills. The individuals assembled to work on this technical assistance request include: Brian Looney, Savannah River Technology Center; Terry Hazen, Lawrence Berkeley National Laboratory; and David Eaton, Idaho Environmental and Engineering National Laboratory. Other participants included David Bourne from DOE-Albuquerque, Jim Davis from DOE Headquarters (EM-34), and Emily Charoglu with EnviroIssues. The biographies of the team members are provided in Appendix A, along with contact information. The scope of this technical assistance request involved the following:

- Examining past efforts at the site to control PCBs in stormwater discharges;

- Reviewing currently proposed short-term activities as part of the draft Settlement Agreement with the Missouri Department of Natural Resources (MDNR); and

- Developing a long-term strategy to address the PCB concern in relation to closure efforts.

These effort involved collecting and reviewing information on the target problem (including background, site history, environmental conditions, technologies and approaches used to combat the problem), identifying critical issues and unresolved issues, determining the best way to further characterize and remediate PCBs, and developing technology matrices to qualitatively rate the technologies according to criteria. The team conducted a two-day assessment to determine ways to minimize risk from the past PCB spills.

\subsection{BACKGROUND}

Historic releases of PCB oil associated with a plastics injection and molding process had released significant quantities of PCBs to soils at KCP. Environmental cleanup activities at the KCP are governed by a RCRA Consent Order enforced by EPA and more recently under a Part B Post Closure Permit enforced by MDNR. MDNR is the state regulatory agency that enforces KCP's National Pollutant Discharge Elimination System (NPDES) stormwater permit. PCB contaminated areas have been characterized under several RCRA Facility Investigation (RFI) projects. Numerous corrective actions have been completed to mitigate PCB infiltration into storm sewer Outfall 002, including: in-situ form lining, encapsulation, soil removal in selected PCB source zones, grout injection, cleaning discharge piping, etc. In general, these actions have reduced PCB levels in the runoff to less than $0.5 \mu \mathrm{g} / \mathrm{L}$, the permit daily maximum discharge limit. However, on occasion PCB levels greater than $0.5 \mu \mathrm{g} / \mathrm{L}$ are detected. Previous versions of the KCP's NPDES permit regulated PCB discharges at one $\mu \mathrm{g} / \mathrm{L}$. However, during the last permit renewal cycle (November 1999) the PCB limit was lowered to $0.5 \mu \mathrm{g} / \mathrm{L}$ effective November 2002. KCP responded to the original discharges and to the subsequent soil and outfall data by implementing a range of actions to mitigate the soil contamination and to reduce the measured PCB releases. These actions were permitted and overseen by environmental 
WSRC-RP-2003-00276

page 2 of 53

regulatory agencies and included: soil removal, altering drainage patterns, lining and cleaning drainpipes and manholes, and other actions. KCP technical personnel have also looked into potential water treatment technologies.

\subsection{PAST EFFORTS TO CONTROL PCBs}

The technical assistance team was impressed with the scientific quality of PCB related studies and support efforts performed by $\mathrm{KCP}$ and their collaborators over the past twenty years. These activities, and the resulting practical outcome-oriented responses, significantly decreased PCB concentrations in Outfall 002 - early concentrations (typically $>5$ $\mu \mathrm{g} / \mathrm{L})$ have declined to levels approaching typical quantitation limits $(<1 \mu \mathrm{g} / \mathrm{L}$ ) (see Figure 1). Notable items in the record documents from KCP: (1) inclusion of a conceptual model of PCB emplacement, migration and accumulation mechanisms in key reports, (2) use of such conceptual models to guide sampling and response plans, (3) presentation of a valid description of cosolvency effects of PCB in the presence of chlorinated solvents (a topic that is often overlooked or incorrectly evaluated), (4) assessing key PCB impacts through ecosystem sampling and other studies to support risk estimation, (5) evaluation and use of emerging technologies such as hydrophobic membrane samplers, and (6) maintaining appropriate controls to assure quality results from the support laboratories.

The team is encouraged by the information that we have seen. We did identify a variety of potential opportunities and have listed these, and associated recommendations, in the appropriate report headings below. We would encourage $\mathrm{KCP}$ to incorporate these, as appropriate, into their plans. In particular, the team was concerned with extended continuation of the existing response concept of "isolating the storm drain system from the residual PCBs". While this approach has generated good PCB reductions in the past, simple isolation is unlikely to provide robust and multi-layered protection. The team felt that the next phase of isolation and reconfiguration activities - those activities that are currently being planned in cooperation with regulators - are generally appropriate. Importantly, the team believes that the most significant PCB reductions are likely to have already been made or will result from these next activities and that significant improvement from future rounds of "storm drain isolation" are unlikely. Instead, we recommend that the site move toward medium-term actions that add additional types of protection to the storm drain system, and long-term actions that consider isolation, destruction or removal of primary PCB sources in the soil and within facilities. 
WSRC-RP-2003-00276

page 3 of 53

\subsection{PATH FORWARD ISSUES}

\section{Critical Issues}

1. Definition of closure is critical. The Office of Environmental Management currently defines closure as: the identification of all sources, implementation of controls and remediation, permitting of immediate remedies by the MDNR, and hand-over to the landlord (NNSA) for completion of remedies and all associated monitoring. With DNAPL PCBs under buildings at the KCP monitoring will have to continue indefinitely.

2. The Settlement Agreement corrective actions are unlikely to result in long-term solutions that further reduce PCB discharges beyond that anticipated for the site since major subsurface sources of PCBs are being left in place.

3. There is a need to periodically characterize source zone PCB plumes and map changes that are occurring over time. Low permeability and unusual geology must be considered in solutions.

4. Mixed contaminants may have implications given the fact that PCB concentrations would be depressed if DNAPL were present.

5. $0.5 \mathrm{ppb}$ recalculation request is unlikely to be considered by MDNR until the Settlement Agreement corrective actions have been implemented.

6. The actions being taken for the $95^{\text {th }}$ Terrace may have implications for residual PCBs and controls for the 002 Outfalls in the near future.

7. The collection of samples at the 002 Outfall and other areas by grab method increases the variability of long-term trends and the probability of exceeding the PCB limit. Composite sampling on weekly or monthly time frames would provide a more accurate and realistic representation of the amount of $\mathrm{PCB}$ contamination that is contributed by the 002 Outfall to the creek. While the KCP has previously requested composite sampling to determine permit compliance, this is in the hands of MDNR via the NPDES outfall permitting program. Even if the MDNR will not officially accept composite sampling for compliance purposes, the KCP is urged to undertake this sampling to obtain a better understanding of the PCBs in the Outfall.

8. The low permeability of the sediment at KCP $\left(10^{-6}-10^{-4} \mathrm{~cm} / \mathrm{sec}\right)$ is an overarching factor that will control the ability to efficiently and cost-effectively use any technology to remediate the PCB source areas at KCP. 
WSRC-RP-2003-00276

page 4 of 53

\section{Unresolved Issues}

1. NNSA acceptance of long-term stewardship responsibilities needs to be formalized - it is the Office of Environmental Management's intention to close the KCP for restoration activities by 2006. This means that all sources of contamination will be identified. All permits granted and all remediation efforts completed or implementation begun. NNSA will then be expected to take over long-term monitoring and completion of any remediation efforts in progress. NNSA may be reluctant to take on these responsibilities at "closure" by EM.

2. The $0.5 \mathrm{ppb}$ PCB standard as an outfall limit for 002 was recently imposed upon the site after routine analytical analyses had improved to make $0.5 \mathrm{ppb}$ a defensible quantitation limit. This suggests that the outfall standard could become a continuously moving target for the KCP as analytical techniques continue to improve. This could make the Plants' ability to meet the standard increasing difficult with time.

3. Identification of all pathways that are the major contributors to the PCBs observed at the 002 Outfall is an extremely difficult issue and likely to be a "Don Quixote" activity over the long-term. While major sources of subsurface PCB contamination around buildings and process areas have been characterized, the parts of the storm sewer that may be contributing to the 002 Outfall concentration changes have been chased for a number of years with fairly good effect. Unfortunately, the levels of PCBs at the 002 Outfall are now so low, that further tracking and identification of sources is going to become increasingly difficult and more expensive due to analytical capabilities unless a more innovative and comprehensive sampling program is implemented.

4. Supplementary science studies to support risk assessment need to focus on topics that address large uncertainties or answer key questions. For example, traditional bioconcentation studies (those that estimate bioconcentration and bioaccumulation factors) are likely have modest effect on risk while studies of particular site issues and that test hypotheses are potentially more useful. The team was encouraged by the study of mollusks as a biomonitor to determine upstream PCB presence in a sessile species as an example of a useful study. Past stream and bioconcentration studies while required by the MDNR and used in the risk assessment model by KCP, have had limited utility in setting 002 Outfall limits. KCP should be encouraged to use these MDNR mandated risk studies to maximize data that can be presented to the state to modify the existing 002 Outfall limit.

5. The schedule and funding for both short-term and long-term solutions is very uncertain and contentious for all parties involved (NNSA, EM and KCP), especially considering the rapidly changing mission for all three entities.

6. Cost of short-term solutions relative to the long-term solutions have not been fully considered. It appears that total life cycle costs of long-term monitoring and remedial 
WSRC-RP-2003-00276

page 5 of 53

actions for short-term lower cost fixes may end up being much higher than the life cycle cost that involves more remediation and a higher initial cost.

\subsection{PATH FORWARD RECOMMENDATIONS}

\section{Short-Term Efforts}

\section{$\underline{\text { Settlement Agreement Corrective Actions }}$}

The team agrees that many of the actions being considered in the Settlement Agreement will contribute to the goal meeting the PCB compliance standard for KCP Outfall 002. This report refers to those actions as short-term actions to differentiate those actions from other actions that might be necessary to address residual PCB contamination that is not perceived as posing an immediate threat. Specifically the team believes that the following short-term actions proposed by the KCP will reduce the amount and concentration of PCBs released into Indian Creek.

\section{Identifying Source of Contamination}

Investigative sampling (semi-permeable membrane devices). Semi-permeable membrane sampling devices (SPMDs) should be placed in the strategic locations to identify possible sources of PCB contamination that may occur episodically. The team believes a refinement of the current stormwater sampling approach could provide more valuable information. The site has already completed a round of sampling with SPMDs and additional work is scheduled. See the section on additions to the Settlement Agreement for details.

\section{Removing Sources of Contamination}

The following actions are currently planned by the KCP:

Rerouting of roof drains below Department $26(\mathrm{D} / 26)$ - Rerouting of the roof drains that traverse $\mathrm{D} / 26$ area such that they do not pass through an area of know PCB contamination in the Outfall 002 system should reduce the potential for contaminating this water. Eliminating or encapsulating that area of contamination would probably provide more permanent results. However, building access constraints complicate such efforts.

Clean outfall 002 main trunk lines-Regular cleaning of the outfall lines should be done to remove either residual contamination or contamination resulting from the settling of PCB contaminated solids as they are transported through the outfall system from other source areas. Removal of solids from sediment traps is currently done when the sediment depth reaches a depth of one inch or more. The depth is measured during semi-annual inspections. Improvements to this approach might be considered and are listed in the next section.

Remove or encapsulate PCB tar coating on roof support structures - Removing the PCB contaminated tar coating would ensure that this material does not contribute to the PCBs released 
WSRC-RP-2003-00276

page 6 of 53

from Outfall 002. Alternatively the PCBs could be encapsulated to immobilize them so that they are not released. While encapsulation does not provide a permanent solution, it may be sufficient to reduce the PCBs exiting the outfall from this source. The team did not identify any improvements to this system.

Remove PCB contaminated sediments from roof-Removing PCB contaminated sediments from the roof will prevent their introduction into the storm sewer.

\section{Other Actions}

Bioaccumulation studies appear to be gathering interesting, but under utilized data. Proposed suggestions to the Settlement Agreement in the next section attempt to put this information to work.

Institutional controls are currently planned for the $95^{\text {th }}$ Terrace site. Until appropriate measures are identified these institutional controls should prevent intrusion into the contaminated zone that could lead to increased movement of those PCBs to surface waters.

As each incremental removal action for PCBs is accomplished, it should be expected that there would be a related reduction in the overall PCB releases or potential for releases from the site. However as long as major sources of contamination remain at the site either in the building, under the building, or in unremediated spills, it may be difficult to completely eliminate PCB releases to Indian Creek. Chasing PCB contamination to prevent sub-ppb levels of PCBs may end up being very costly and time consuming.

The team suggests that the Settlement Agreement schedule calling for a report 180 days after implementation be delayed until sufficient data can be obtained to determine the effectiveness of the actions taken. Historical data shows higher levels of PCBs in the summer along with higher precipitation levels. A full year of data would be desirable, but 6 months of data is minimally essential depending upon the time of year that corrective actions are completed. The report would then be due 120 days after sufficient data had been collected.

\section{$\underline{\text { Additional Recommendations for Settlement Agreement }}$}

There appear to be significant opportunities for short-term enhancements to current approaches for measuring and controlling PCBs. The KCP may want to consider adding some of these actions to their proposal during negotiation of the Settlement Agreement. The following ideas were considered of merit by the team.

\section{Composite Sampling}

The team suggests a modification of the current sampling approach. The team understands that this will require negotiation with the MDNR before an alternative approach can be used for compliance determination. The team suggests that the current approach of weekly grab samples does not meet the intent of demonstrating compliance with NPDES permits. The team believes that some form of composite sampling would be more appropriate. This could be accomplished 
WSRC-RP-2003-00276

page 7 of 53

with the deployment of an ISCO (brand name or equivalent) automatic type sampler. In this manner a sample could be collected that would be representative of the entire week rather than a point in time. This type of sampler could also be tied to volumetric flow rates so that the sampler takes proportionally larger samples during periods of higher flows. Other states and EPA require the use of automatic or proportional sampler to ensure representative sample data. Even if the MDNR does not allow the use of this data for compliance purposes, this data may be of use to the KCP in their continuing quest to identify and remove sources of PCBs that are being released into Indian Creek. See Appendix C for details on Delaware Estuary Alert.

\section{Comparative Sampling}

The team suggests that the KCP aggressively pursue the identification and removal of sources of PCBs to Outfall 002. In this process it is important to not only measure PCB concentrations, but also to measure flow rates and generate a "mass balance" within the system. For example the single pass cooling water represents $80-90 \%$ of the normal flow in Outfall 002, but its overall contribution to the PCBs exiting the outfall may be insignificant.

The team suggests that the KCP develop a comparative sampling plan that could be used to more accurately target removal or control activities. For example, during steady state flow conditions, samples could be gathered at multiple locations. Analysis would then take place in a step-wise manner. First the outfall sample would be analyzed. If elevated levels were found, samples from further up the outfall would continue to be analyzed until the contamination was isolated. This would probably be an iterative process identifying and removing the more significant sources of PCBs as a first priority. An alternative or complementary approach would use integrating samplers such as the semi-permeable membranes discussed below.

\section{Utilization of Semi-Permeable Membrane}

Semi-permeable membrane sampling could also be used to determine PCB concentrations at specific locations integrated over time. These samplers could be used to determine relative concentrations of PCBs at various locations in the outfall. KCP would also have to measure flow rates from various waste streams that contribute to this outfall. With this data, KCP should be able to quantify, at least proportionally, the amount of PCBs that each part of the system is contributing. This should assist the KCP in targeting future corrective actions in those areas that will do the most good. This effort is currently underway.

\section{Rerouting of Single Pass Cooling Water}

The single pass cooling water is either a major source of PCBs to the outfall or a major source of dilution. Treatment and reuse of the single pass cooling water or routing that water to the industrial or sanitary sewer could produce significant changes to the amount of PCBs in the outfall. The single pass cooling water now represents approximately $80-90 \%$ of the normal flow of the outfall. If it contains PCBs near or above the outfall limit, removing that source will definitely contribute to overall compliance. On the other hand, if the single pass cooling water is well below the $0.5 \mathrm{ppb}$ and this source of dilution is removed, then the outfall concentrations of PCBs will dramatically increase. A side benefit to this increase though would be that any 
WSRC-RP-2003-00276

page 8 of 53

remaining sources of PCB contamination should be easier to identify. However, the overall volume of PCB discharges would not change unless identified and addressed.

\section{Utilization of Bioaccumulation Studies}

The team suggests that the KCP work with the regulators and stakeholders on a way to utilize the bioaccumulation studies to tie those results to the establishment of an effluent standard. It is the team's understanding at this point that the currently proposed effluent standard is based on the PQL for PCB from commercial laboratories. The team concurs with KCP that repeatedly lowering the standard to match the march of analytical science is inappropriate. A process should be negotiated that sets the effluent standard based on risk to the recreational fisherperson, the PQL, and existing conditions in the river. The KCP should investigate the use of alternative PCB analytical procedures. Pace Laboratories in Minneapolis has been identified as one of several labs specializing in analysis of low PCB concentrations. KCP should look at EPA Method 1668.

\section{Sediment Removal or Treatment}

KCP plant personnel indicated that PCB levels rise in the days after a precipitation event. KCP should consider the probability that the storm event deposits PCB laden sediment into the outfall system. Much of the sediment will be trapped in the sediment traps. After the precipitation has ceased, it is possible that these fresh sediments are leached of their PCBs by the now slow moving water. Sampling of these sediments immediately after a precipitation event might reveal whether this is a significant factor in the PCBs being released into Indian Creek. If this approach reveals significant PCB source material, then KCP should consider cleaning the sediment traps more frequently or installing some type of absorption media (such as activated carbon) in the sediment traps to capture the PCBs. The activated carbon could be replaced during the six month inspection.

\section{Eliminate All Non-Storm Water Sources to Outfall}

The team suggests that the KCP establish a goal of eliminating all flow from the storm sewer outfall system during dry weather and normal operations. KCP should identify and repair leaking water lines and storm sewer lines.

\section{Renegotiate Compliance Standard}

If all reasonable corrective actions are implemented and the outfall still exceeds the $0.5 \mathrm{ppb}$ standard, KCP should prepare appropriate justification for discussions with the regulators. If the proposed standard based upon an unsubstantiated practical quantitation limit (PQL) is not reasonably achievable, then there should be room for negotiation. Data gathered as part of the six sigma review should be reinforced with appropriate data. The team is somewhat concerned that alternative analytical methodologies may be available that dramatically lower the PQL. Appendix D provides a list of analytical labs specializing in low PCB analysis for KCP evaluation. 
WSRC-RP-2003-00276

page 9 of 53

\section{Periodic Chromatographic Analysis}

PCBs are mixtures of 209 different compounds ("congeners") that have various degrees of chlorination and positioning of the chlorine atoms on the aromatic rings. PCBs can be biodegraded aerobically and anaerobically, and will naturally weather the longer they are in the environment. PCB congeners can also change as a result of transport (heavier congeners stay in place while lighter congeners may move). Thus, shifts in the congener distributions in chromatograms over time may indicate the amount of weathering and biodegradation that has occurred or provide evidence that the PCBs are moving (or are not moving). Semi-annual or annual chromatogram comparisons would provide the site with a low cost line of evidence that natural attenuation may be occurring at the site and overtime an index of how fast (Butcher et al., 1997). It is imperative that this analysis be based on composite samples rather than grab samples that might represent varying sources of PCBs as a result of operational or meteorological conditions.

\section{Medium-Term Efforts to Reduce PCBs at the 002 Outfall}

The team believed the past and present storm sewer protection and isolation efforts could be supplemented by a medium-term activity to attenuate the low concentrations of PCBs that bypass the protections enter the storm sewer. This would add a layer of protection. By providing a different class of response, the overall system can be made more robust and PCB fluxes can be more reliably reduced and stabilized. All of the proposed options would require creative and careful engineering to overcome site-specific challenges such as large storm surges and changes in water elevation in Indian Creek. All of the supplemental medium-term actions discussed by the team involve PCB attenuation from the base flow using filtration, sorption, settling and similar techniques. Large storm surges and any reverse flows from within the 002 storm sewer Indian Creek during storms would generally contain few PCBs and could be handled by appropriate bypass systems. The team felt that three possible systems might be viable. These were: (1) a wetland treatment cell, (2) trench based treatment, and (3) a small standard package treatment plant. A variant of this strategy that uses the existing surge basin may represent a relatively low cost option. Each of the three systems and the promising variant are described in turn below along with some of the advantages, disadvantages and uncertainties. All of the options described in this section will require modifications to include a lift station to deliver water to the surface, an attenuation cell or treatment unit, a system to return water to the storm sewer, and a system to handle storm events and high water. All of the options described in this section will require an analysis to make sure that the increased infiltration does not adversely impact nearby levees or any existing soil contamination.

There is a significant body of scientific literature related to the use of wetlands to treat contaminants such as PCBs. While some of this research is specific to particular wetland types (e.g., sphagnum peat bogs), the papers generally suggest that wetlands are relatively capablestable-sustainable systems for attenuating PCBs. Such systems rely on several mechanisms sorption to organic matter, settling and filtration, and biological degradation. There are several challenges to wetland based actions at Outfall 002. The most significant of these is the lack of available land between the main facility and Indian Creek. This area is occupied by a highway, levee, parking areas, utilities, former landfills, and other cultural features. A few locations, such 
as the existing Outfall 002 surge basin and some of the existing parking lots might be considered if a wetland appears promising and cost effective upon further analysis. Many types of wetland treatment cells are possible. Appendix E provides more detail and an example modular system (EPA 1999), which maintains isolation of the storm water from the subsurface.

An alternative configuration, trench based attenuation or treatment, would reduce the required footprint. In this implementation, the stormwater is passed through a trench filled with a treatment media. A trench system is similar in concept to an in situ permeable treatment bed or wall for groundwater - the principal difference being the ability to engineer the sizing and control the flow better. The system is also analogous to a treatment plant that uses sorption columns - the principal difference being the ability to use large volumes of low cost media. Such media could be a coarse carbon substrate, a natural and biologically stable material such as peat or (if needed) a sorbent resin (e.g. XAD). Additional data would be needed to design a trench treatment to minimize the potential for plugging, maximize beneficial microbial degradation and minimize any adverse microbial activity. A trench system would be particularly sensitive to storm surge and would need careful design to minimize problems after implementation.

A more traditional system would utilize a small (circa 50 to 100 gpm) package treatment plant as the attenuation step. While such systems are often relatively inexpensive to buy, implementation might be hampered by the modifications needed to adapt to the unusual site needs - driving up costs. Operation and maintenance costs for packaged treatment systems are often high and secondary wastes from packaged plants can be significant unless they are conscientiously minimized. A challenge and uncertainty associated with packaged treatment plants is that most such systems have not been designed or tested with effluent concentration targets of $0.5 \mathrm{ppb}$. Packaged treatment systems would have the smallest footprint of the medium-term strategies and would have the lower initial costs than most other options (except the use of the existing surge basin described below). The packaged treatment plant would minimize any problems associated with increased infiltration because positive control is maintained on the water during treatment.

The team identified a promising variant of the medium-term options that might be viable, implementable, and relatively low cost. This variant would use the existing surge basin to provide hydraulic residence time and would attenuate and stabilize PCBs by the mechanisms settling, filtration and sorption. Over time a wetland would be established and this would be a small opportunistic wetland treatment implementation. As noted above the general requirements of this system include a lift station and a storm surge bypass. The adverse impacts of this option include less storm surge handling capacity and the increased infiltration. Uncertainties include: 1) the completeness of attenuation and if the system would have sufficient area and volume, 2) potential impact related to downgradient contamination associated with the $95^{\text {th }}$ Terrace site, and 3 ) potential to impact slope stability and the levee. A positive feature of this concept is the overall reduction in volume of stormwater release to surface water (with a direct concomitant reduction in PCB impacts) and the increase of groundwater elevation that would serve to reduce flow rates under the KCP facility. Despite the limitations and uncertainties, the team felt that this option was worthy of follow up conceptual design work and discussion. If, after such additional effort, the option is still considered promising, remaining issues such as infiltration 
WSRC-RP-2003-00276

page 11 of 53

near the levee could be addressed cooperatively with the Army Corps of Engineers and with additional input from the technical assistance team as required.

\section{Long-Term Strategies (Source Control)}

Efforts to decrease releases of PCBs to levels that are "as low as reasonably achievable" and to minimize exceedances of sub $\mu \mathrm{g} / \mathrm{L}$ targets may require efforts to directly address the sources within facilities and in the soil. PCBs within facilities are addressed using standard operational controls, isolation methods (epoxy coatings and the like), and surface decontamination methods. Addressing high strength PCB wastes that have already been released into the soil represents a significant challenge and will require additional data and careful planning - the team has generated a technology matrix that identifies key issues and uncertainties to assist KCP in this challenging stage. As shown in the matrix, some of the technologies are not well matched to the $\mathrm{KCP}$ site, due to the low permeability for example. Some technologies may not provide sufficient benefit to justify their cost or may in fact cause collateral damages to the environment that offset their benefits. The technology matrix and the discussion below are organized according the classes of actions that can be used to address high strength PCBs in soil: (1) institutional control and monitored natural attenuation, (2) destruction methods, (3) immobilization and isolation methods and (4) enhanced removal methods.

\section{$\underline{\text { Institutional Control and Monitored Natural Attenuation }}$}

The source zone PCBs in the soil at KCP appear to be relatively stable and have not spread rapidly away from their original deposition and emplacement locations. An appropriate conceptual model of PCB migration and emplacement is presented in several KCP reference documents - this model describes gravitational migration downward through discrete vertical flow paths ultimately resulting in emplacement in thin accumulation layers in which limited lateral movement occurs. The limitations on the extent of lateral movement result from the finite size of the PCB release and the ultimate balancing of the "forward pressure" of separate PCBs phase with the entry pressure of the oil into the pores. In low permeability clay sediments such as those at KCP, PCBs would be expected to remain near the original release location. Similarly, for PCBs in the subsurface near more other types of nonaqueous phase liquids (NAPLs, e.g., solvents such as trichloroethylene) the PCBs preferentially partition into the NAPL where they are held in place until the bulk NAPL phase is cleaned up. In this case, the PCB concentrations in the groundwater are depressed by the presence of the solvent NAPL (Raoult's Law is often used to estimate the various concentrations). These descriptions suggest that the primary residual sources of PCBs at KCP are relatively stable and would be expected to remain stable - i.e., in their current configuration -- for an extended period of time. As a result, they are unlikely to pose an imminent hazard or risk and they may not pose an unacceptable future risk.

Because of the favorable geological setting this may be one of the unusual sites where residual high strength source PCBs can be left in place within the context of a brownfield industrial use. Further information and support would be needed to make such a case and the lifecycle costs of such an action may be increased by the amount of data and documentation needed to support the 
claim of "no unacceptable risk". Two cases of limited action are assessed in a technology matrix provided in Table 1 below.

Considering such limited actions for high concentration PCB sources over long periods of time requires careful and serious evaluation. Institutional control would have to be maintained in perpetuity. Because of the stability of $\mathrm{PCBs}$, monitored natural attenuation is not promising as a method to reduce the source over time. In fact, a study by ORNL (1998) at KCP indicated low microbial populations, low microbial diversity, low levels of nutrients and low responses to stimulation in microcosms. These data were "consistent with the clayey environment" and indicated that MNA may not be active for TCE (or by extension, the more recalcitrant PCBs) at the KCP site. Similar to the sections below, ORNL suggested that some other options may be possible but concluded their analysis with "Indications are, however, continued monitoring will be sufficient.... \{This monitoring\} would permit careful consideration of whether any remedial measures would be cost-effective." The technical assistance team generally concurs with the ORNL investigators. We believe that institutional control may be viable and that MNA processes (without enhancement) are likely to be ineffective for PCBs. 
Table 1: Technology Matrix - No Further Action/Monitored Natural Attenuation Technologies

\begin{tabular}{|c|c|c|c|c|c|c|c|c|c|c|}
\hline Approach & Strategy & Effectiveness & $\begin{array}{l}\text { Permitting } \\
\text { Risk }\end{array}$ & $\begin{array}{l}\text { Implement- } \\
\text { ability }\end{array}$ & $\begin{array}{l}\text { Health and } \\
\text { Safety Issues }\end{array}$ & Cost* & $\begin{array}{l}\text { Public } \\
\text { Acceptability } \\
\text { (Stakeholder) }\end{array}$ & $\begin{array}{l}\text { Long- } \\
\text { term } \\
\text { Liability } \\
\end{array}$ & $\begin{array}{l}\text { Technical } \\
\text { Maturity }\end{array}$ & Overall \\
\hline $\begin{array}{l}\text { Institutional } \\
\text { Control }\end{array}$ & $\begin{array}{l}\text { Institutional } \\
\text { controls }\end{array}$ & $\begin{array}{l}\text { No effect on } \\
\text { source of } \\
\text { PCBs, low }\end{array}$ & $\begin{array}{l}\text { Medium to } \\
\text { high and } \\
\text { requires KCP } \\
\text { develop/prov } \\
\text { e acceptable } \\
\text { risk levels }\end{array}$ & High & $\begin{array}{l}\text { Low, some risk } \\
\text { to worked in } \\
\text { contact with } \\
\text { residual PCBs, } \\
\text { perceived risk } \\
\text { to receiving } \\
\text { creek }\end{array}$ & $\begin{array}{l}\text { Initially low } \\
\text { but requires } \\
\text { significant } \\
\text { monitoring in } \\
\text { perpetuity. } \\
\text { Life cycle } \\
\text { costs would } \\
\text { be high. }\end{array}$ & $\begin{array}{l}\text { Low - failure } \\
\text { to clean up }\end{array}$ & $\begin{array}{l}\text { High - } \\
\text { given the } \\
\text { site } \\
\text { would } \\
\text { leave } \\
\text { PCBs in } \\
\text { place }\end{array}$ & NA & $\begin{array}{l}\text { Team has } \\
\text { reservations } \\
\text { about using } \\
\text { no further } \\
\text { action as } \\
\text { long-term } \\
\text { response }\end{array}$ \\
\hline $\begin{array}{l}\text { Monitored } \\
\text { Natural } \\
\text { Attenuation }\end{array}$ & $\begin{array}{l}\text { Same as } \\
\text { above }\end{array}$ & $\begin{array}{l}\text { MNA of PCBs } \\
\text { poor }\end{array}$ & $\begin{array}{l}\text { Same as } \\
\text { above }\end{array}$ & $\begin{array}{l}\text { Same as } \\
\text { above }\end{array}$ & Same as above & $\begin{array}{l}\text { Same as } \\
\text { above but } \\
\text { would } \\
\text { require more } \\
\text { extensive } \\
\text { monitoring } \\
\end{array}$ & $\begin{array}{l}\text { Same as } \\
\text { above }\end{array}$ & $\begin{array}{l}\text { Same as } \\
\text { above }\end{array}$ & $\begin{array}{l}\text { Same as } \\
\text { above }\end{array}$ & $\begin{array}{l}\text { Same as } \\
\text { above }\end{array}$ \\
\hline
\end{tabular}

${ }^{*}$ Cost: low $<\$ 5$ million, moderate $>\$ 5-\$ 20$ million, high $>\$ 20-\$ 50$ million; very high $>\$ 50$ million 
WSRC-RP-2003-00276

page 14 of 53

\section{$\underline{\text { Destruction }}$}

The technical assistance team evaluated several remedial technologies. Below is discussion of the technologies, grouped by remedial strategy: biological, chemical, or physical.

\section{Biological Strategies}

Bioremediation of organics in situ can be accomplished by biostimulation or bioaugmentation. Bioaugmentation is the injection of microorganisms into the subsurface to facilitate biodegradation. This technique can be useful for freshly contaminated environments but requires high permeability since it involves injection of particles into the subsurface. Given the low permeability of the KCP soils bioaugmentation is not appropriate and will not be considered further. Biostimulation involves the injection of nutrients (liquid or gas) into the subsurface to stimulate indigenous microbes to degrade organic contaminants in situ. As a general rule injection of liquid nutrients can be accomplished down to hydraulic conductivities of $10^{-7} \mathrm{~cm} / \mathrm{sec}$ and gas down to $10^{-9} \mathrm{~cm} / \mathrm{sec}$. Since the KCP site in general has conductivities from $10^{-6}$ to $10^{-4}$ $\mathrm{cm} / \mathrm{sec}$ and a very poor recharge rate, injection of anything including gases will be difficult. However, gas injection may present the greatest opportunities for biostimulation. For the purposes of this evaluation, the target concentration for bioremediation is assumed to be 10 parts per million (ppm) for PCBs (based on previous KCP activities, 1993). As bioremediation of PCBs is known to occur in both anaerobic and aerobic environments, both modes should be considered (Focht, 1993). In aerobic environments, chlorines can be removed and ring cleavage may occur in many congeners with relatively few chlorine substitutions. For congeners with higher numbers of chlorines, aerobic degradation is either slow or not feasible. Thus, removal of a high percentage of the PCBs is not likely with aerobic degradation alone, but removal of small fractions of the PCBs (primarily congeners that have fewer substitutions and are also more mobile) via aerobic degradation is achievable. Bioremediation of PCBs in many applications is ruled out due to high concentrations and the low efficiency of most PCB biodegradation. A strategy of sequencing aerobic and anaerobic conditions has been shown to result in the complete destruction of PCBs in soil (Rogers et al., 1999). However, it should be cautioned that the ability of bioremediation strategies alone to reach the cleanup standard for KCP of $10 \mathrm{ppm}$ in soil would be difficult and require a fairly long period of time (years), given the DNAPL concentrations that are known to exist at many areas in the KCP site. Recently, biostimulation has been used frequently as a polishing step in a treatment train after initial chemical oxidation with Fenton's, peroxide or ozone. Aerobic and anaerobic bioremediation strategies are described and evaluated below.

\section{A. Aerobic Bioremediation}

Aerobic bioremediation is a proven technology in which aerobic microorganisms degrade chlorinated compounds by various mechanisms. Deployment of aerobic bioremediation requires sufficient oxygen and inorganic nutrients (Hazen, 1997). In addition, the presence of easily degradable organic carbon is sometimes necessary or can increase rates of degradation of target compounds. In some cases, contaminated soils may contain sufficient levels of degradable carbon and only oxygen addition is required. In other cases, oxygen is provided in addition to degradable organic substrates, delivered in solid, liquid or gaseous additions. The accumulation 
of unwanted degradation intermediates does not usually occur with aerobic bioremediation, since degradation is usually complete to inorganic components (Focht, 1993). In nearly all environments the other organic contaminants present will be more degradable than the PCBs (Hickey, 1999). A biotreatability study would be recommended for aerobic bioremediation of soils. These studies are used to demonstrate feasibility and provide an opportunity to optimize the bioprocess for a site. At KCP, previous studies have demonstrated that anaerobes are present and that the ability to degrade chlorinated solvents is also present, although the density of microorganisms and their activity is quite low $\left(<10^{4}\right.$ cells/g soil) (ORNL, 1998). The most probable reason for this is the low permeability, and undetectable concentrations of nitrogen and phosphorus (essential nutrients) at nearly all sites sampled (ORNL, 1998). The oxygen concentration is also quite low and would suggest existence of excess carbon and energy sources that could be stimulated by injection or infiltration of other limiting nutrients (N \& P) and oxygen. Given the low background numbers of microbes and the low permeability of these environments biodegradation under aerobic stimulation alone would be slow and is likely to leave residual concentrations of PCBs for long periods of time.

\section{B. Anaerobic Bioremediation}

Anaerobic bioremediation is a proven technology in which anaerobic microorganisms degrade chlorinated solvents by the mechanism of reductive dehalogenation. This microbial activity requires strongly anaerobic conditions and the presence of anaerobic microorganisms possessing reductive dehalogenation capability. In cases where natural conditions do not support anaerobic reductive dehalogenation, it is common to deploy biostimulation (addition of carbon sources to produce anaerobic conditions) as well as bioaugmentation (addition of anaerobic bacteria shown to degrade the contaminant) to achieve in situ anaerobic biodegradation of chlorinated compounds (Hickey, 1999). In anaerobic environments, PCBs can undergo reductive dehalogenation that results in reduction of the average number of chlorines on the rings but does not necessarily result in ring cleavage. Typically, congeners with fewer substitutions undergo reductive dehalogenation at a slower rate. Thus, concentrations of congeners with fewer substitutions can rise as those with more substitutions fall. Thus, many scenarios for PCB degradation envision alternating anaerobic phases and aerobic phases to degrade congeners with fewer substitutions. However, if concentrations much lower than $100 \mathrm{ppm}$ were required for as a cleanup criteria, a combination of anaerobic degradation (to reduce chlorine substitution) and aerobic degradation (for ring cleavage and removal of chlorine from congeners with few chlorines) could be employed. Anaerobic biostimulation may also increase methane production in the subsurface to the extent that methane could accumulate to explosive levels underneath the buildings at the site. This would be an additional health and safety concern for this technology. Note: aerobic biostimulation does not result in methane accumulation because methogens cannot survive under aerobic conditions.

In summary, aerobic degradation appears to be a better option than anaerobic degradation and is a potentially viable low-cost option for the KCP soils, since gases could be injected for the aerobic biostimulation. This technology is likely to be difficult due to the low permeability of the soils and the difficulty with injection of nutrients. More passive technologies like infiltration galleries at several key points at the site may allow a lower cost, albeit longer term remediation solution (see Figure 2 of a standard infiltration gallery design). The effectiveness would likely 
be medium to low due to the low permeability and the presence of DNAPL concentrations. The permitting should be relatively simple due to the general acceptability of bioremediation with naturally occurring bacteria. Aerobic degradation is a relatively simple technology, analogous to farming and will be easy to implement. Nutrient delivery effectiveness may be an issue for the regulators. The safety and health issues should below unless anaerobic alone conditions caused buildup of methane underneath buildings. Potential costs are medium to low, especially if longterm infiltration galleries are used. These infiltration galleries have minimal M\&O requirements and once constructed would only involve the periodic addition of nutrients at monthly or quarterly intervals. The technical maturity of aerobic degradation is not high, as the goal of high percentages of degradation has been limited in in situ degradation studies, but the levels of degradation targeted in this application are achievable over long periods of time or in combination with other treatment trains. Stakeholder acceptance should be high, as costs are low and the public generally views bioremediation favorably. Long-term liability is medium due to the potential for incomplete or slow destruction of PCBs. Technical maturity is medium to low due to limited experiences with low permeability environments and DNAPL concentrations of PCBs in situ. This technology may be preferable as a slow long-term, low cost implementation that attacks the PCB source.

Figure 2. Typical Infiltration Gallery

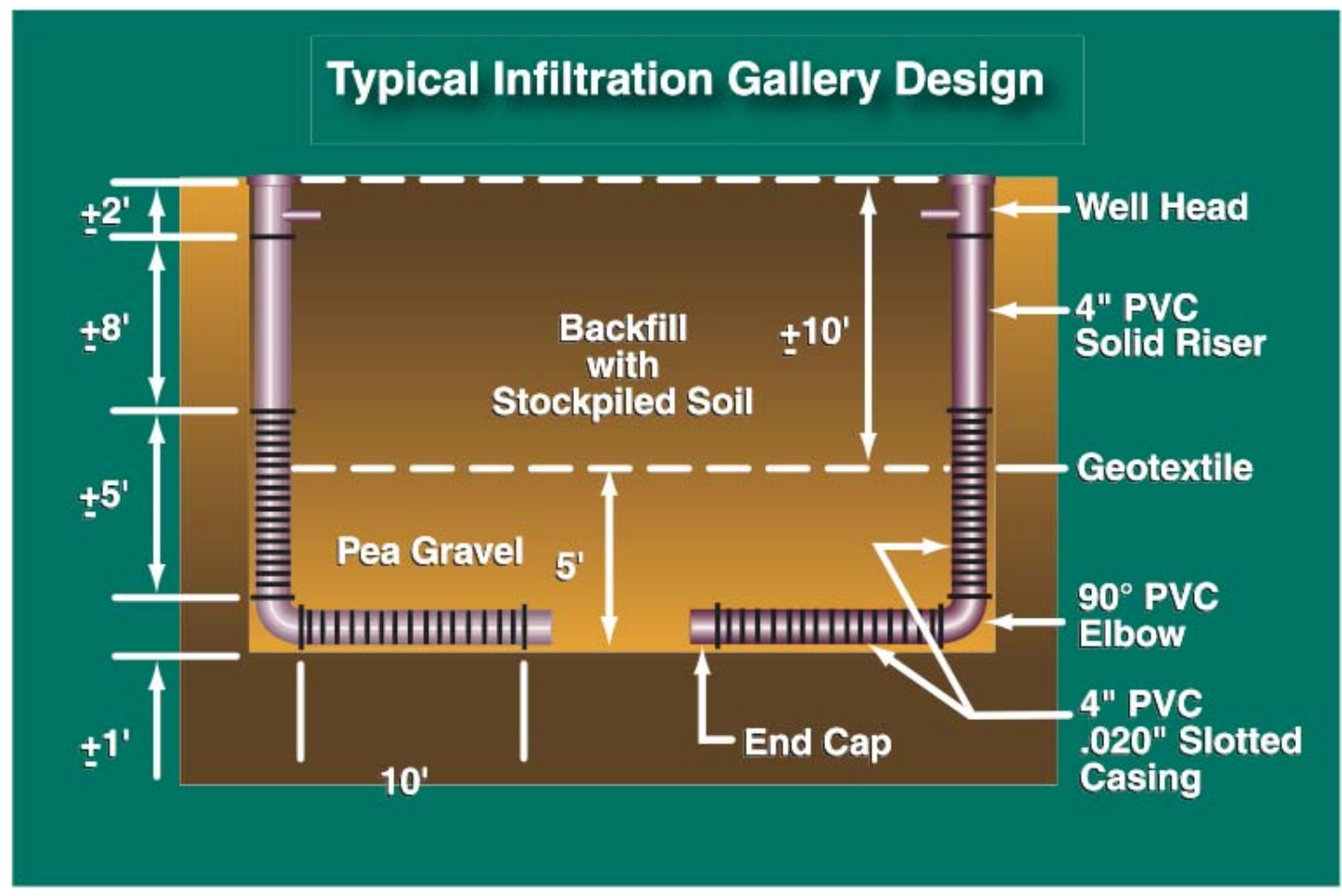


WSRC-RP-2003-00276

page 17 of 53

\section{Chemical Strategies}

Recommended chemical strategies are oxidation with potassium permanganate, Fenton's reagent, or peroxide; and reduction with iron, inorganic alkali, or nucleophilic reagents. A third chemical strategy, electrochemical treatment, is described but not recommended.

\section{Chemical Oxidation}

Chemical oxidation has been used for wastewater treatment and has recently emerged as a viable technique for treating organics in contaminated soil and groundwater. There are a variety of specific oxidation methods that have been developed, as shown in the following overview of the types of oxidants that are used or being tested for PCBs. This is then followed by a brief discussion on how chemical oxidation can be applied to KCP in situ PCB sources and a preliminary assessment of its viability.

Direct Oxidation at Ambient Temperature. In this approach, an oxidant is directly applied to the soil either in a batch reactor or in situ. Three types of oxidants have been used most frequently for organics: (1) Fenton's reagent, (2) permanganate, and (3) ozone. 1. Fenton's reagent has been investigated most extensively for the oxidation of PCBs although most of the published results are on its use as a pretreatment for subsequent biodegradation of PCBs (e.g., Aronstein and Rice, 1995). The lack of published results using Fenton's reagent alone for removing PCBs may be an indication that this is not a viable process. There is, however, one vendor (ManTechClean-Tox) that claims to treat PCBs in soil using Fenton-like proprietary chemicals.

Unpublished laboratory studies at ORNL showed that $76 \%$ of 2,5,2-TCB in artificially spiked sandy sediment $(0.46 \mathrm{mg} / \mathrm{kg}$ initial $)$ was removed in 5 hours using $3 \mathrm{~mL}$ of $8.5 \%$ peroxide on $3 \mathrm{~g}$ of sediment. Note that byproduct formation was not investigated in this study and complete mineralization of the 2,5,2'-TCB was not established. Furthermore, Sedlak and Andren (1994) showed that oxidation rate of $\mathrm{PCBs}$ by $\mathrm{OH}^{*}$ was significantly slower when the PCBs were adsorbed to diatomaceous earth, particularly for the more highly chlorinated congeners. In their experiments, 2,5,2' - TCB was still oxidized in the presence of particulate matter but 2,2',4,2'TeCB was not oxidized at all within the time-scale of their experiments. Thus, despite the positive results at ORNL, Fenton's reagent may have limited effectiveness for degrading more highly chlorinated PCB congeners. 2. There are no published studies on using permanganate for oxidizing PCBs. ORNL laboratory studies using permanganate on 2,5,2-TCB and 2,2',4,2TeCB showed limited removal in soils (20 to 30\%). 3. A recent publication (Cassidy et al., 2002) describes laboratory-scale ozonation of artificially spiked kaolinite and river sediment followed by biodegradation of ozonation byproducts. Significant PCB removals $(>90 \%)$ by ozonation alone were achieved in 30 days. The reaction times were on the order of 30 to 50 days. One of the PCBs tested was a highly chlorinated congener, 2-,3-,4-,2'-,3'-,4'hexachlorobiphenyl (HCB). 
WSRC-RP-2003-00276

page 18 of 53

\section{Application of Chemical Oxidation at KCP}

Direct chemical oxidation using Fenton's reagent or ozone is possible. These can be applied by applying oxidants in situ. The advantage of in situ application is its ability to accommodate slower reaction kinetics. However, homogeneous distribution of oxidant throughout the contaminated soil may be a problem. An even greater problem will be the ability to deliver oxidants to the contaminated soil due to the poor permeability. There are other methods of chemical oxidation that are possibly available, including steam distillation/electrochemical peroxidation and supercritical oxidation. However, these techniques will require specialized equipment that may not yet be commercially available. Thus, only direct chemical oxidation using Fenton's reagent or ozone is considered below. Effectiveness of chemical oxidation is low to moderate. Ozonation may be more effective, given results from Cassidy et al. (2002). In either case, complete mineralization will likely have to be achieved by biodegradation. For Fenton's reagent, significant amounts of reagent liquid may have to be applied to the soil, given the levels of PCBs. There are health and safety concerns due to the handling of reactive fluids and pressurized vessels. Excess liquids for Fenton's reagent will have to be handled appropriately. These concerns, in combination with the relatively high cost, suggest that stakeholder acceptability would not be high. Costs would be primarily for the oxidant and delivery system. Ozone generators are available (and not that expensive), but may incur energy and operator costs. Technical maturity is low to moderate, as there is little experience with PCBs, especially for ozonation. Overall, oxidation is viable but problematic due to insufficient removal to achieve target levels, excess liquids from addition of Fenton's reagent, the need to control $\mathrm{pH}$. It may best be used as a pretreatment for bioremediation if needed.

\section{E. Chemical Reduction}

Several developers have been working on chemical-reduction based soil treatment systems. These systems use chemical reagents to abiotically reduce the organic contaminants, such as PCBs. Over the past several years, vendors have been coupling this process with traditional soil washing operations. This coupling of technology is appropriate since soil washing, normally effective because of physical particle size separation, requires the soil to be finely divided and mixed with fluids for transfer and elutriation. Such systems are positioned to perform chemical reactions, such as redox reactions, by simply adding the necessary chemicals to the existing equipment after assuring compatibility with process containers, pumps, etc. Alternative implementations are also possible, such as blending the soil with elemental iron and adding moisture. The result of any of the treatments is a large volume of cleaned soil residual, and depending on the implementation, a small volume of secondary process waste. The characteristics, advantages and disadvantages of chemical reduction using liquid reagents and chemical reduction using blended solids are addressed in turn. Chemical reduction is generally performed as a batch process. The contaminated soil is loaded into a contained system where it is blended and/or contacted with the reducing reagent. A few reagents (a reagent mixture), mostly proprietary, have been proposed. These include "nascent hydrogen" generated from an elemental metal and acid, various implementations of a nucleophilic reagent and excess alkali (high $\mathrm{pH}$ ), and a solid phase blending of zero-valent iron and moisture with the soil, followed a period of reaction. Only a few test results have been widely reported. Researchers in Norway 
reported that chemical reduction amended soil washing is relatively effective for appropriate soils (e.g., "400 ppm PCB treated to $<10$ ppm under ideal conditions"). Other research, while showing some promise, suggests caution in selecting this technology. For example, in the EPA Superfund Innovative Technology Evaluation program, the "original caustic based system" was "ineffective in destroying PCBs" and a final report was not published. According to the EPA project manager, the Superfund Innovative Technology Evaluation program technology developer (Trinity Environmental Technologies) has continued to investigate improvements, including temperature controls, better mixing, and more aggressive reagents and is developing a one ton per hour modular system for deployment. In general, bench scale lab experiments under ideal conditions show reasonable treatment (e.g., "2000 mg/Kg to $<2 \mathrm{mg} / \mathrm{Kg}$ "). Nonetheless, additional work may be needed before this method can be reliably deployed for a reasonable and certain cost.

Addition of a granular reagent, such as zero-valent iron to the soil will generate conditions to abiotically dehalogenate some chlorinated organic compounds. In this implementation, granular zero-valent iron would be mixed with the soil and with water to provide appropriate conditions for the abiotic contaminant destruction. It is likely that the quantity of reagent needed and need for homogeneity would require removal of the soil and external mixing. After mixing, the soil could be replaced to allow reaction time, if the aggressive chemistry in the soil (high $\mathrm{pH}$ and low dissolved oxygen) that would occur in the facility is acceptable. Conditions in the soil would be monitored and optimized to insure sufficient degradation. Zero-valent iron has often been deployed in permeable walls and similar configurations and has been studied by a large number of university/federal laboratories and companies. Researchers from the University of Waterloo in Canada performed early development of the technology - the principal licensee of their work is EnviroMetal. Importantly, zero-valent iron has not been extensively studied for treating PCBs and PCBs are not listed by the vendor on its table of compounds that have been tested as treatable by the reagent. The core zerovalent iron technology is low-cost, but implementation for this particular soil is limited by uncertainty in the effectiveness for dechlorinating PCBs, the low permeability, and the associated costs. Based on the literature, chemical reduction is unlikely to be viable for treatment of KC Plant soils in situ. Relative to the other technologies described in the matrix, chemical reduction is very immature and unlikely to be cost effective. Because of this and the unique nature of the KCP PCB soil problem, additional scientific study would be needed prior to final design and costing.

\section{F. Electrochemical Treatment}

Electrochemical treatment is a recently proposed and implemented technology that uses electrical current as the central component of a system to decontaminate contaminated soil in place. Similar to the more aggressive direct energy thermal techniques (e.g., six-phase heating and radiofrequency heating), these treatments rely on injecting electromagnetic energy directly into the bulk soil. Thus, the considerations of geology, water content, etc. are similar between these methods and the related thermal methods. The key difference in these "treatment" methods is the additional implementation and documentation of a destruction or detoxification mechanism in the deployment process. Two variants, at different levels of maturation, are discussed below. These are the Lasagna technology and the ElectroChemical Remediation Technology (ECRT). The most successful electrochemical treatment to date is the Lasagna 
system developed and implemented by a consortium of federal researchers (DOE, EPA and others), industry and universities. Lasagna is primarily an electroosmosis process that relies on moving water through the subsurface. This technology exploits phenomena in which ions in the diffuse double layer near soil particles move in response to a DC electric field and induce water movement in a parallel direction via shear forces, or drag at the double layer interface. The unique feature of Lasagna is placing layers of treatment or capture material in the path of the moving water so that the contaminants are efficiently detoxified as they move over relatively short distances. The system also minimizes the problems sometimes associated with the chemistry near the electrodes by treating the contaminants relatively far away within the target treatment volume. While the basics of this technology are well established from industrial applications in dewatering and clay consolidation, fully reliable performance for remediation applications has yet to be established. The technology is most applicable to saturated or near saturated sediments with low permeability (e.g., $<10^{-5} \mathrm{~m} / \mathrm{s}$ hydraulic conductivity). Within this bound, the method has low power consumption and will induce a relatively uniform flow that is "independent" of heterogeneity. For organics, the method is limited to the soluble fraction and will not remove residual non-aqueous phase solvents in the system, nor will it treat tightly bound contaminants. This is a serious limitation for PCBs because of their relatively high affinity for soils and makes the Lasagna variant of electrochemical treatment nonviable for KCP soil. ECRT is a recent technology that has been investigated in Europe (P2-Soil Remediation, Inc) and in the United States (by Weiss and Associates in partnership with the developers). The technology advocates suggest that soil can be decontaminated using much lower current densities than Lasagna or heating methods. In particular, they indicate that organics such as PCBs can be effectively treated in place by "induced oxidation" processes that they designate Electrochemical GeoOxidation (ECGO). The claims are supported by patents (US 5,738,778 and 5,596,644) and by limited field data. Importantly, the developers do not have controlled documentation about the destruction process and do not know mechanism of destruction, nor its robustness. They speculate that "these reactions occur at any and all interfaces within the soil" and that "an induced polarization field is produced ... \{leading to $\}$... disharges of electricity to occur ... \{and that $\}$... in the electrical discharge, REDOX reactions take place." It is unlikely that "discharges" are occurring at the power densities employed; significant additional research is needed before this method can be reliably used. As with most other direct energy processes, the data suggest that reaction rate is inversely proportional to grain size and that moisture is needed in the system. Based on the case studies, the proposed technology is intriguing and, if substantiated by additional research, may be important in the future. Despite their isolation and available environment, the conditions at KCP do not appear ideal for ECRT/ECGO. Most importantly, however, the technology is sufficiently immature that the project could not be performed in any mode except a research mode - significantly increasing costs for monitoring and incurring potential schedule risk. Based on the available information, this technique would be viable if it performed as claimed by its vendor. These claims appear optimistic and deployments should be selected carefully to minimize potential downside risks if the technology fails, while at the same time encouraging disciplined technology development for this type of inexpensive and potentially revolutionary method. According to Weiss Associates, the active redox zone reacts and destroys organics while metals migrate to both electrodes for easy collection and removal. Treatment is reportedly cost effective, but does take months. Several examples of remediation using this technology in Europe, including one for PCB, are cited by the developers. Despite the reported success in Europe, the team did not recommend this 
WSRC-RP-2003-00276

page 21 of 53

technology because of its immaturity and its limited track record. Even if the technology works, the understanding of the basic mechanisms is limited, despite the explanations in the vendor literature.

\section{G. Physical Treatment Strategies}

Thermal technologies are the only physical treatment technologies that would potentially destroy PCBs in situ. In situ vitrification is the only thermal technology that could potentially reach the temperatures necessary to destroy PCBs in situ. Because the costs would be very high and the implementability over wide areas of the site to a depth that has never been demonstrated before (40 ft.) this technology is not viable and is not recommended for KCP in situ PCB treatment.

Table 2 further examines and qualitatively compares the PCB destruction alternatives. 
Table 2. Technology Matrix - PCB Destruction Technologies

\begin{tabular}{|c|c|c|c|c|c|c|c|c|c|c|}
\hline Approach & Strategy & Effectiveness & $\begin{array}{l}\text { Permitting } \\
\text { Risk }\end{array}$ & $\begin{array}{l}\text { Implement- } \\
\text { ability }\end{array}$ & $\begin{array}{l}\text { Health and } \\
\text { Safety Issues }\end{array}$ & Cost* & $\begin{array}{l}\text { Public } \\
\text { Acceptability } \\
\text { (Stakeholder) }\end{array}$ & $\begin{array}{l}\text { Long-term } \\
\text { Liability }\end{array}$ & $\begin{array}{l}\text { Technical } \\
\text { Maturity }\end{array}$ & Overall \\
\hline $\begin{array}{l}\text { Liquid } \\
\text { Biostim- } \\
\text { ulation }\end{array}$ & $\begin{array}{l}\text { Addition of } \\
\text { nutrients to } \\
\text { generate } \\
\text { conditions } \\
\text { leading to } \\
\text { PCB } \\
\text { destruction }\end{array}$ & $\begin{array}{l}\text { Medium to low } \\
\text { because of } \\
\text { incomplete } \\
\text { destruction. } \\
\text { Hydraulic } \\
\text { conductivity } \\
\text { limiting at site. }\end{array}$ & $\begin{array}{l}\text { Medium to } \\
\text { high because } \\
\text { regulators may } \\
\text { not accept. } \\
\text { Delivery } \\
\text { effectiveness } \\
\text { may be an } \\
\text { issue. Would } \\
\text { require a UIC } \\
\text { permit. }\end{array}$ & $\begin{array}{l}\text { Med-low, } \\
\text { depends on } \\
\text { permeability } \\
\text {. Requires } \\
\text { close } \\
\text { spacing of } \\
\text { wells for } \\
\text { very slow } \\
\text { delivery } \\
\text { with } \\
\text { infiltration } \\
\text { galleries. }\end{array}$ & $\begin{array}{l}\text { Low - } \\
\text { minimal risk. } \\
\text { In } \\
\text { methanogenic } \\
\text { conditions, } \\
\text { some gas } \\
\text { build up. }\end{array}$ & $\begin{array}{l}\text { Medium } \\
\text { to low }\end{array}$ & $\begin{array}{l}\text { Medium to } \\
\text { high }\end{array}$ & $\begin{array}{l}\text { Medium - } \\
\text { potential } \\
\text { for } \\
\text { incomplete } \\
\text { or slow } \\
\text { destruction }\end{array}$ & $\begin{array}{l}\text { Medium to } \\
\text { low - } \\
\text { limited } \\
\text { experience } \\
\text { with low } \\
\text { permeability } \\
\text { and PCBs } \\
\text { might use in } \\
\text { combination } \\
\text { with other } \\
\text { methods or } \\
\text { as a } \\
\text { polishing } \\
\text { step } \\
\text { (treatment } \\
\text { train) }\end{array}$ & $\begin{array}{l}\text { May be } \\
\text { viable } \\
\text { preferable } \\
\text { as slow } \\
\text { long-term } \\
\text { low cost } \\
\text { implement } \\
\text { ation }\end{array}$ \\
\hline $\begin{array}{l}\text { Gas } \\
\text { Biostimu- } \\
\text { lation }\end{array}$ & $\begin{array}{l}\text { Same as } \\
\text { above }\end{array}$ & $\begin{array}{l}\text { Same as above, } \\
\text { gas delivery } \\
\text { somewhat } \\
\text { easier than } \\
\text { liquid }\end{array}$ & $\begin{array}{l}\text { Medium - UIC } \\
\text { may be easier } \\
\text { than liquid }\end{array}$ & $\begin{array}{l}\text { Medium to } \\
\text { low }\end{array}$ & $\begin{array}{l}\text { Low - should } \\
\text { not produce } \\
\text { methane }\end{array}$ & $\begin{array}{l}\text { Less } \\
\text { viable, } \\
\text { more } \\
\text { costly } \\
\text { than } \\
\text { infiltrati } \\
\text { on } \\
\text { gallery }\end{array}$ & $\begin{array}{l}\text { Same as } \\
\text { above }\end{array}$ & $\begin{array}{l}\text { Same as } \\
\text { above }\end{array}$ & $\begin{array}{l}\text { Same as } \\
\text { above }\end{array}$ & $\begin{array}{l}\text { May be } \\
\text { viable }\end{array}$ \\
\hline $\begin{array}{l}\text { Chemical } \\
\text { Destruction }\end{array}$ & $\begin{array}{l}\text { Chemical - } \\
\text { oxidation } \\
\text { (potassium } \\
\text { permangana } \\
\text { te, Fenton's } \\
\text { Reagent, } \\
\text { and } \\
\text { Peroxide) } \\
\text { and } \\
\text { reduction } \\
\text { (iron, }\end{array}$ & $\begin{array}{l}\text { Same } \\
\text { effectiveness as } \\
\text { biostimulation } \\
\text { - medium to } \\
\text { low }\end{array}$ & $\begin{array}{l}\text { Medium to } \\
\text { high because } \\
\text { regulators may } \\
\text { not accept. } \\
\text { Delivery } \\
\text { effectiveness } \\
\text { may be an } \\
\text { issue. Would } \\
\text { require a UIC } \\
\text { permit - may } \\
\text { be difficult to }\end{array}$ & $\begin{array}{l}\text { Low - } \\
\text { difficult, } \\
\text { requires } \\
\text { closely } \\
\text { spaced wells }\end{array}$ & $\begin{array}{l}\text { Medium to } \\
\text { high - } \\
\text { requires } \\
\text { handling of } \\
\text { strong } \\
\text { oxidants in } \\
\text { pressurized } \\
\text { system. }\end{array}$ & High & $\begin{array}{l}\text { Medium - } \\
\text { only } \\
\text { acceptable } \\
\text { because it } \\
\text { destroys } \\
\text { source }\end{array}$ & $\begin{array}{l}\text { Medium - } \\
\text { there is a } \\
\text { potential } \\
\text { for } \\
\text { incomplete } \\
\text { destruction } \\
\text { (residuals) }\end{array}$ & $\begin{array}{l}\text { Medium to } \\
\text { low for this } \\
\text { type of site }\end{array}$ & $\begin{array}{l}\text { Low } \\
\text { viability - } \\
\text { significant } \\
\text { reservatio } \\
\text { ns }\end{array}$ \\
\hline
\end{tabular}


WSRC-RP-2003-00276

page 23 of 53

\begin{tabular}{|c|c|c|c|c|c|c|c|c|c|c|}
\hline Approach & Strategy & Effectiveness & $\begin{array}{l}\text { Permitting } \\
\text { Risk }\end{array}$ & $\begin{array}{l}\text { Implement- } \\
\text { ability }\end{array}$ & $\begin{array}{l}\text { Health and } \\
\text { Safety Issues }\end{array}$ & Cost* & $\begin{array}{l}\text { Public } \\
\text { Acceptability } \\
\text { (Stakeholder) }\end{array}$ & $\begin{array}{l}\text { Long-term } \\
\text { Liability }\end{array}$ & $\begin{array}{l}\text { Technical } \\
\text { Maturity }\end{array}$ & Overall \\
\hline & $\begin{array}{l}\text { inorganic } \\
\text { alkaline, and } \\
\text { nucleophilic } \\
\text { reagents) }\end{array}$ & & obtain & & & & & & & \\
\hline $\begin{array}{l}\text { Oxidants } \\
\text { and } \\
\text { Reduct- } \\
\text { ants }\end{array}$ & $\begin{array}{l}\text { Chemical } \\
\text { reduction } \\
\text { and } \\
\text { dechlorinati } \\
\text { on }\end{array}$ & $\begin{array}{l}\text { Low - } \\
\text { uncertain } \\
\text { because of } \\
\text { limited data to } \\
\text { indicate that it } \\
\text { would work }\end{array}$ & Same as above & $\begin{array}{l}\text { Same as } \\
\text { above }\end{array}$ & $\begin{array}{l}\text { Medium - } \\
\text { Nature of } \\
\text { chemicals has } \\
\text { less risk }\end{array}$ & High & $\begin{array}{l}\text { Medium to } \\
\text { low - destroys } \\
\text { source but } \\
\text { may require } \\
\text { high pH and } \\
\text { other } \\
\text { conditions less } \\
\text { desirable to } \\
\text { stakeholders } \\
\end{array}$ & $\begin{array}{l}\text { Medium - } \\
\text { given } \\
\text { residuals }\end{array}$ & $\begin{array}{l}\text { Low - not } \\
\text { much data, } \\
\text { some lab } \\
\text { studies }\end{array}$ & Not viable \\
\hline $\begin{array}{l}\text { Electro- } \\
\text { chemical }\end{array}$ & $\begin{array}{l}\text { Electrically } \\
\text { driven } \\
\text { simultaneou } \\
\text { s } \\
\text { oxidation/re } \\
\text { duction }\end{array}$ & $\begin{array}{l}\text { Low to } \\
\text { medium given } \\
\text { high } \\
\text { uncertainty - } \\
\text { vendor claims } \\
\text { it works well in } \\
\text { clays }\end{array}$ & $\begin{array}{l}\text { High - given } \\
\text { uncertainties } \\
\text { and lack of } \\
\text { data }\end{array}$ & $\begin{array}{l}\text { Medium - } \\
\text { the design } \\
\text { concepts are } \\
\text { in their } \\
\text { infancy }\end{array}$ & $\begin{array}{l}\text { Low, some } \\
\text { risk to worked } \\
\text { in contact } \\
\text { with residual } \\
\text { PCBs }\end{array}$ & Medium & $\begin{array}{l}\text { Medium - } \\
\text { good concept, } \\
\text { no data }\end{array}$ & $\begin{array}{l}\text { Medium to } \\
\text { high - too } \\
\text { many } \\
\text { uncertaintie } \\
\mathrm{s} \text {, likely to } \\
\text { leave } \\
\text { residuals }\end{array}$ & Low & $\begin{array}{l}\text { Team } \\
\text { believes it } \\
\text { is too } \\
\text { early for } \\
\text { applicatio } \\
\mathrm{n} \text { at this } \\
\text { site. }\end{array}$ \\
\hline $\begin{array}{l}\text { In Situ } \\
\text { Vitrifi- } \\
\text { cation }\end{array}$ & $\begin{array}{l}\text { Heating to } \\
\text { high } \\
\text { temperature } \\
\text { s to destroy } \\
\text { PCBs }\end{array}$ & High & High & $\begin{array}{l}\text { Low - not } \\
\text { implementa } \\
\text { ble }\end{array}$ & High & $\begin{array}{l}\text { Very } \\
\text { high }\end{array}$ & $\begin{array}{l}\text { Low - } \\
\text { difficult to } \\
\text { understand } \\
\text { technology }\end{array}$ & $\begin{array}{l}\text { Low - } \\
\text { immobile } \\
\text { solid } \\
\text { remains }\end{array}$ & Low & Not viable \\
\hline
\end{tabular}

*Cost: low $<\$ 5$ million, moderate $>\$ 5-\$ 20$ million, high $>\$ 20-\$ 50$ million; very high $>\$ 50$ million 
WSRC-RP-2003-00276

page 24 of 53

\section{$\underline{\text { Isolation/Immobilization }}$}

Because of site-specific conditions, isolation stabilization and/or immobilization of high strength PCBs in soils may be viable at this site. The favorable conditions include a generally low permeability in the system and the bedrock limiting the vertical and lateral extent of hydrologic and relevant geologic system. In this setting where production wells yield only a "few gallons a minute" and where PCBs appear to be near their original emplacement locations isolation and immobilization options are somewhat more aligned with exploiting and enhancing the natural situation, whereas some of the treatment or removal options that require injection and extraction of fluids are challenged by the natural conditions. Despite these favorable factors, the technical assistance team cautions that leaving high strength PCB sources may result in future impacts because of the stability of PCBs in such a setting this liability would extend over long time frames (circa 100s of year or longer). Given these constraints, if a sustainable and stable isolation could be implemented by appropriate supplementation of natural conditions, it may be a good selection for this facility. Several stabilization options were evaluated and advantages, disadvantages and uncertainties tabulated. The options included various forms of: physical barriers (sheet pile walls, freeze walls, caps), hydraulic barriers, grout and colloidal silica injection barriers, permeable barriers, and hydrophobic chemical barriers. Each of these is discussed briefly below.

\section{Sheet Pile and Other Engineered Walls and Caps}

There is a wide range of engineering and construction technologies to install subsurface barriers. An effective barrier for minimizing future spread of high strength PCB sources requires partially or completely circumscribing the source and keying the system into the impermeable rock below the active hydrologic system. These requirements are challenging, especially at a site such as KCP with a specific issue of limited access in the presence of buildings, roads, utilities, and other cultural features and interferences. This particular approach also requires large construction operations and has significant risks of accident or occupational injury. The placement of a physical barrier around the residual source may provide a reasonable assurance to regulators and stakeholders that the material will be isolated and will pose little future risk. The longevity of such a barrier would need to be documented because of the extreme time frame associated with PCB residuals in highly contaminated soils. A further consideration is that "onesided" downgradient cutoff walls are often ineffective. Groundwater flow simply bypasses the system after a short period of pressure equilibration. The need for partially or fully circumscribing wall systems increases the costs and difficulty of installation at a site like KCP. The consensus of the team was that limited barrier installation might be viable (and could be considered in combinations with other strategies) but that this technology is not recommended as a primary choice due to costs and risks.

\section{Freeze Walls}

Two variants of this technology are possible: (1) freeze a barrier around the PCB source area, and (2) freeze the contaminated source volume. Both of these would require a large refrigerant plant and access infrastructure (wells, refrigerant circulation systems etc.). The integrity of the wall concept could not be assured and might not be accepted by stakeholders and regulators. 
Conversely, freezing the actual source zone would be robust but more costly. In either case, freezing is only a temporary solution because the time frame of PCB stability is large and the system would need to be run in perpetuity. The technology requires somewhat less access than sheet pile walls, but would have difficulty in treating material beneath buildings. Because of high costs and poor long-term performance, the team does not recommend this approach. Also, because of the significant infrastructure needed for deployment, this technology may not be attractive for small-scale use in combination with other strategies (future developments by the industry may make small targeted application more viable in the future).

\section{Hydraulic Barriers and Hydraulic Controls}

This technology uses large-scale modification of the hydrologic system to reduce flow and minimize contaminant flushing. Hydraulic controls attempt to prevent contaminated water from reaching certain regions of the aquifer or prevent clean water from contacting contaminated source regions. These technologies include control through injection downgradient of the contaminant source region, or control through diversion or extraction upgradient of the source. Note that repair and maintenance activities to limit leaking water lines are presumed.

KCP has already noted the impact of a fortuitous downgradient injection resulting from a leaking water line - this leak slowed the migration of the VOC plume and the plume spread southward after the leak was repaired. This type of system has several risks and uncertainties such as the potential to accelerate the release of contamination that is already beyond the injection area, and the need for permanent (albeit low cost) operation, maintenance and documentation. Upgradient water control management, especially if the water is clean, is low cost, moderately low risk and easily implemented. As with downgradient controls, upgradient hydraulic controls require a long-term operational commitment to be effective. Hydraulic controls may be appropriate supplementary technologies. Both types will have high long-term risk, reflecting the duration over which these systems would need to be operated. The team does not generally recommend these technologies as a long-term solution but believes that they may be useful in meeting near term goals. Moreover, if data and risk assessment show that the residual sources are relatively stable and only limited supplementary methods would assure risk reduction performance, a passive version of this technology might be applied. In this configuration, upgradient "geosiphon" wells (such as those developed at the Savannah River Site) or high evapotranspiration plantings (such as have been applied at Portsmouth and other sites) would extract water. The system would target clean water entering the system from the bluffs to the north along with infiltration north of the major site plume(s). For the geosiphon, the difference in elevation between the water level in the wells and the receiving Blue River provides the motive force for water flow from the wells via a siphon. The result would be a reduction in the driving force through the groundwater system minimizing flow through PCB and VOC source zones. The system would need to be carefully designed to pump an appropriate quantity of water to flatten the gradient without inducing flow toward the siphon. More modeling (or addition of appropriate scenarios to existing models) would be useful to properly design and document a geosiphon system. If the system needed to be installed in an area of dissolved VOC contamination, the siphon outlet could be treated with an easily maintained and long-lived iron ex situ iron module prior to entering the stream. A geosiphon/phytoextraction may be viable at this site. 
Figure 3. Simplified Diagram of Geosiphon Concept - A. Baseline Conditions, B. with control

A.
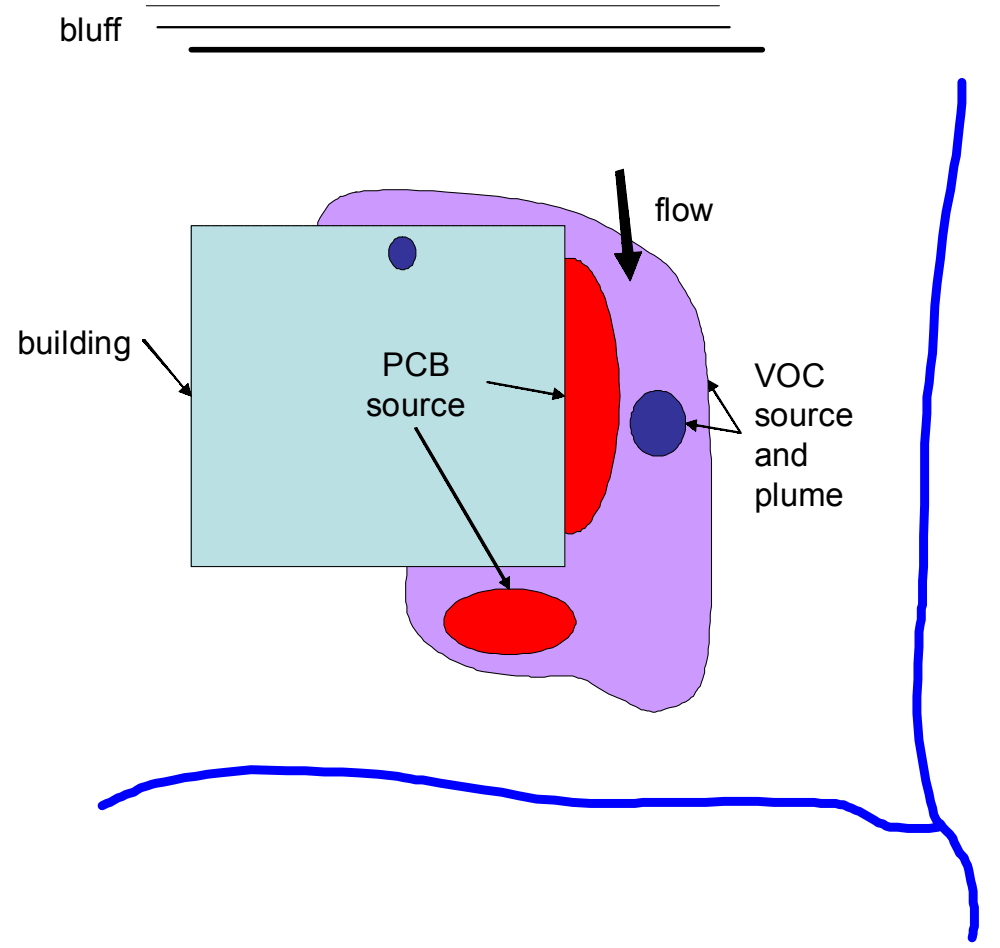

B.

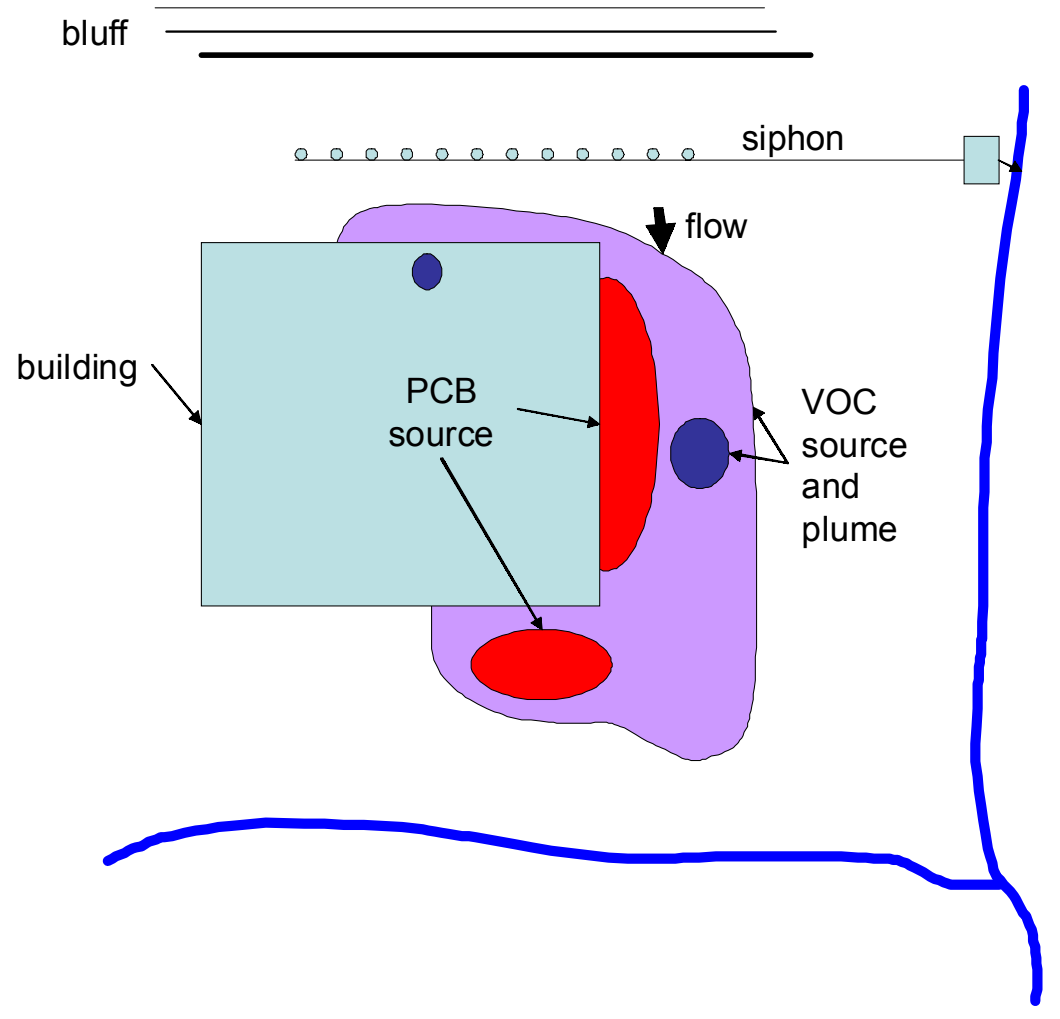


WSRC-RP-2003-00276

page 27 of 53

\section{Grout and Injected Colloidal Silica Barriers}

These barriers are installed by injecting a flowable sealant into the system by forming an in situ barrier. This technology originated in the oilfield and has been modified for environmental applications. The DOE LBNL viscous barrier (Heiser et al., 1999) is a relatively mature version that uses colloidal silica injection followed by a controlled gelling process. Other flowable barrier materials have also been studied (Whang, 1995). While a promising technology in general, this type of barrier has limited applicability to low permeability systems such as KCP. Reliable installation would be challenging and documentation difficult. Although potentially less expensive than some of the other immobilization methods, the team does not recommend this technology for $\mathrm{KCP}$ because of site-specific conditions.

\section{Permeable Barrier}

This technology utilizes a treatment material in a permeable trench or structure. The intercepted water is treated as it flows through the system and "clean" water is "discharged". This technology has been the subject of active research throughout the world with investment by universities (Waterloo and others), companies (e.g., Envirometal Technologies, Inc. and others), and all relevant federal agencies. The most common treatment material for VOCs is granular iron ("zero-valent iron"), amended granular iron, sorbents derived from industrial byproducts, or waste organic material for redox control. In the case of iron, the barrier provides an environment that dehalogenates chlorinated VOCs as they pass through because of the high energy of the surface corrosion reaction and the high surface area. The primary problems with this technology relate to the chemistry of the water exiting the barrier, which often has a high $\mathrm{pH}(>10)$ and no dissolved oxygen. Other problems include low treatment flow rate, especially in low permeability materials, sometimes expensive installation, and unknown lifetime of the barrier materials. This technology is limited in applicability for PCBs at KCP because of low flow and lack of significant delivery to the system combined with the relatively short lifetimes of the barrier vis-à-vis the required source isolation period. Most estimates for barrier lifetime are 10 to 20 years rather than the 100 s or 1000 s needed in this case.

Table 3 further examines and qualitatively compares the PCB isolation/immobilization alternatives. 
Table 3. Technology Matrix - PCB Isolation/Immobilization Technologies

\begin{tabular}{|c|c|c|c|c|c|c|c|c|c|c|}
\hline Approach & Strategy & Effectiveness & $\begin{array}{l}\text { Permitting } \\
\text { Risk }\end{array}$ & $\begin{array}{l}\text { Implement- } \\
\text { Ability }\end{array}$ & $\begin{array}{l}\text { Health and } \\
\text { Safety Issues }\end{array}$ & Cost* & $\begin{array}{l}\text { Public } \\
\text { Acceptability } \\
\text { (Stakeholder) }\end{array}$ & $\begin{array}{l}\text { Long- } \\
\text { term } \\
\text { Liability }\end{array}$ & $\begin{array}{l}\text { Technical } \\
\text { Maturity }\end{array}$ & Overall \\
\hline $\begin{array}{l}\text { Sheet Pile } \\
\text { Walls }\end{array}$ & $\begin{array}{l}\text { Physical } \\
\text { barriers } \\
\text { installed } \\
\text { using } \\
\text { standard } \\
\text { construction } \\
\text { methods }\end{array}$ & $\begin{array}{l}\text { Low to } \\
\text { medium } \\
\text { depending on } \\
\text { construction } \\
\text { and how } \\
\text { complete } \\
\text { isolation is }\end{array}$ & $\begin{array}{l}\text { Medium - } \\
\text { given source } \\
\text { stays in place }\end{array}$ & $\begin{array}{l}\text { Low because } \\
\text { of buildings } \\
\text { and } \\
\text { interference } \\
\text { of } \\
\text { infrastructure }\end{array}$ & $\begin{array}{l}\text { High - large } \\
\text { construction } \\
\text { equipment }\end{array}$ & High & $\begin{array}{l}\text { Medium - } \\
\text { protective } \\
\text { barrier viewed } \\
\text { as a positive } \\
\text { but source left } \\
\text { in place }\end{array}$ & $\begin{array}{l}\text { Low to } \\
\text { medium - } \\
\text { leaves the } \\
\text { source in } \\
\text { place, } \\
\text { potential } \\
\text { for barrier } \\
\text { failure }\end{array}$ & $\begin{array}{l}\text { Medium to } \\
\text { high }\end{array}$ & $\begin{array}{l}\text { Not } \\
\text { recommended } \\
\text { as a primary } \\
\text { solution } \\
\text { because of } \\
\text { interferences } \\
\text { and logistics } \\
\text { but could be } \\
\text { used in } \\
\text { conjunction } \\
\text { with other } \\
\text { strategies }\end{array}$ \\
\hline $\begin{array}{l}\text { Freeze } \\
\text { Walls }\end{array}$ & $\begin{array}{l}\text { In situ } \\
\text { formed ice } \\
\text { barrier or } \\
\text { source zone }\end{array}$ & $\begin{array}{l}\text { Medium - } \\
\text { prevents near- } \\
\text { term migration }\end{array}$ & $\begin{array}{l}\text { Medium - } \\
\text { given } \\
\text { uncertainties } \\
\text { and questions } \\
\text { about } \\
\text { impacts of } \\
\text { freezing }\end{array}$ & $\begin{array}{l}\text { Low - } \\
\text { requires a } \\
\text { large } \\
\text { refrigeration } \\
\text { plant }\end{array}$ & $\begin{array}{l}\text { Medium - } \\
\text { given } \\
\text { construction } \\
\text { requirements }\end{array}$ & High & Medium & $\begin{array}{l}\text { High - } \\
\text { requires } \\
\text { PCBs } \\
\text { remain in } \\
\text { place. } \\
\text { Permanent } \\
\text { commitme } \\
\text { nt to leave } \\
\text { in place or } \\
\text { take } \\
\text { alternate } \\
\text { action }\end{array}$ & $\begin{array}{l}\text { Low to } \\
\text { medium }\end{array}$ & $\begin{array}{l}\text { Not } \\
\text { recommended } \\
\text { due to high } \\
\text { cost and poor } \\
\text { long-term } \\
\text { performance }\end{array}$ \\
\hline $\begin{array}{l}\text { Hydraulic } \\
\text { Control }\end{array}$ & $\begin{array}{l}\text { Water } \\
\text { injection or } \\
\text { withdrawal } \\
\text { to minimize } \\
\text { flow and } \\
\text { transport }\end{array}$ & $\begin{array}{l}\text { Medium in } \\
\text { short-term and } \\
\text { as long a } \\
\text { system } \\
\text { maintained }\end{array}$ & $\begin{array}{l}\text { If injection } \\
\text { used, High - } \\
\text { requires UIC } \\
\text { permit, is a } \\
\text { temporary } \\
\text { solution, } \\
\text { leaves PCBs } \\
\text { in place, and } \\
\text { may spread } \\
\text { source } \\
\text { If extraction }\end{array}$ & $\begin{array}{l}\text { Medium - } \\
\text { straightforwa } \\
\text { rd }\end{array}$ & $\begin{array}{l}\text { Low - no } \\
\text { handling of } \\
\text { high } \\
\text { concentration } \\
\text { wastes, simple } \\
\text { construction, } \\
\text { etc. }\end{array}$ & Low & Low & $\begin{array}{l}\text { Active } \\
\text { system, } \\
\text { high due } \\
\text { to source. } \\
\text { Passive } \\
\text { system } \\
\text { such as } \\
\text { geosiphon } \\
\text { medium to } \\
\text { high. }\end{array}$ & High & $\begin{array}{l}\text { Injection } \\
\text { based, Not } \\
\text { recommended } \\
\text { Extraction } \\
\text { based may be } \\
\text { viable }\end{array}$ \\
\hline
\end{tabular}


WSRC-RP-2003-00276

page 29 of 53

\begin{tabular}{|c|c|c|c|c|c|c|c|c|c|c|}
\hline Approach & Strategy & Effectiveness & $\begin{array}{l}\text { Permitting } \\
\text { Risk }\end{array}$ & $\begin{array}{l}\text { Implement- } \\
\text { Ability }\end{array}$ & $\begin{array}{l}\text { Health and } \\
\text { Safety Issues }\end{array}$ & Cost* & $\begin{array}{l}\text { Public } \\
\text { Acceptability } \\
\text { (Stakeholder) }\end{array}$ & $\begin{array}{l}\text { Long- } \\
\text { term } \\
\text { Liability } \\
\end{array}$ & $\begin{array}{l}\text { Technical } \\
\text { Maturity }\end{array}$ & Overall \\
\hline & & & $\begin{array}{l}\text { only, low to } \\
\text { medium }\end{array}$ & & & & & & & \\
\hline $\begin{array}{l}\text { Injected } \\
\text { Barriers }\end{array}$ & $\begin{array}{l}\text { Injection of } \\
\text { grouts or } \\
\text { silica to } \\
\text { form barrier } \\
\text { in place. } \\
\text { Example is } \\
\text { the DOE } \\
\text { Viscous } \\
\text { Barrier }\end{array}$ & $\begin{array}{l}\text { Low given } \\
\text { limited ability } \\
\text { to form and } \\
\text { document a } \\
\text { complete } \\
\text { barrier, } \\
\text { especially in } \\
\text { low } \\
\text { permeability } \\
\text { soils }\end{array}$ & $\begin{array}{l}\text { High - } \\
\text { source left in } \\
\text { place and } \\
\text { integrity of } \\
\text { barrier may } \\
\text { be } \\
\text { questionable }\end{array}$ & Low & $\begin{array}{l}\text { Low to } \\
\text { medium }\end{array}$ & $\begin{array}{l}\text { Medium } \\
\text { to high }\end{array}$ & $\begin{array}{l}\text { Low - source } \\
\text { left in place }\end{array}$ & High & Low & $\begin{array}{l}\text { Not } \\
\text { recommended }\end{array}$ \\
\hline $\begin{array}{l}\text { Permeable } \\
\text { Barriers }\end{array}$ & $\begin{array}{l}\text { Barriers that } \\
\text { contain } \\
\text { treatment } \\
\text { material and } \\
\text { which } \\
\text { attenuate } \\
\text { materials as } \\
\text { water flows } \\
\text { through }\end{array}$ & $\begin{array}{l}\text { Medium - } \\
\text { many treatment } \\
\text { materials to } \\
\text { remove } \\
\text { organics }\end{array}$ & $\begin{array}{l}\text { High - given } \\
\text { variable } \\
\text { performance } \\
\text { of such } \\
\text { systems }\end{array}$ & $\begin{array}{l}\text { Low - given } \\
\text { interferences } \\
\text { and low } \\
\text { permeability }\end{array}$ & $\begin{array}{l}\text { Medium - } \\
\text { construction is } \\
\text { an issue }\end{array}$ & High & $\begin{array}{l}\text { Medium - } \\
\text { given } \\
\text { interferences } \\
\text { and low } \\
\text { permeability }\end{array}$ & $\begin{array}{l}\text { Low to } \\
\text { medium - } \\
\text { leaves the } \\
\text { source in } \\
\text { place, } \\
\text { potential } \\
\text { for barrier } \\
\text { failure }\end{array}$ & $\begin{array}{l}\text { Low to } \\
\text { medium - } \\
\text { given } \\
\text { limited } \\
\text { experience } \\
\text { with PCBs }\end{array}$ & $\begin{array}{l}\text { Not } \\
\text { recommended } \\
\text { - leaves } \\
\text { residual in } \\
\text { place, lifetime } \\
\text { of barriers } \\
\text { unknown }\end{array}$ \\
\hline
\end{tabular}

$*$ Cost: low $<\$ 500,000 ;$ moderate $>\$ 500,000$; high $>\$ 1 \mathrm{M}$; very high $>\$ 5 \mathrm{M}$ 
WSRC-RP-2003-00276

page 30 of 53

\section{$\underline{\text { Removal }}$}

$\mathrm{KCP}$ has historically remediated major releases of PCBs through removal actions. These removal actions were typically driven by a perception of risk to man or his environment. The criteria used to determine the extent of the removal action was typically based on the potential of the contaminant to spread beyond the plant boundaries.

a. The primary method of removal has been excavation and hauling of the PCB contaminated soils to a chemical waste landfill in Alabama. Removal of the soils from the $95^{\text {th }}$ Terrace Site would be possible but would entail a major traffic disruption of Bannister Road.

b. Another method of PCB removal would be to use a surfactant flush. This would entail injecting a surfactant into the PCB contaminated zone through injection wells. Extraction wells would then be used to remove PCBs to be shipped off site for treatment and disposal.

c. Applying heat to the contaminated zone would also mobilize the organic constituents including the PCBs. The mobilized contaminants could then be removed via extraction wells. Heat could be supplied in a variety of ways. These could include steam injection, hot air injection, six-phase heating, microwave, or other technologies that provide heat to the contaminated region. PCBs and other contaminants removed from the system would be shipped off site for treatment and disposal.

d. Some of the PCBs could also be removed via extraction wells that were designed to pump very slowly at the interface between gravel and shale approximately forty feet below surface. While it is extremely unlikely that this technology would prove to be sufficient on its own, it could be used to decrease the total load of PCB contaminated materials so that other technologies might be more successful.

Table 4 further examines and qualitatively compares the PCB removal alternatives. 
Table 4. Technology Matrix - PCB Removal Technologies

\begin{tabular}{|c|c|c|c|c|c|c|c|c|c|c|}
\hline Approach & Strategy & $\begin{array}{l}\text { Effectivenes } \\
\text { s* }^{*}\end{array}$ & $\begin{array}{l}\text { Permitting } \\
\text { Risk }\end{array}$ & $\begin{array}{l}\text { Implement- } \\
\text { ability }\end{array}$ & $\begin{array}{l}\text { Health and } \\
\text { Safety Issues }\end{array}$ & Cost* & $\begin{array}{l}\text { Public } \\
\text { Acceptability } \\
\text { (Stakeholder) }\end{array}$ & $\begin{array}{l}\text { Long- } \\
\text { term } \\
\text { Liability }\end{array}$ & $\begin{array}{l}\text { Technical } \\
\text { Maturity }\end{array}$ & Overall \\
\hline Removal & $\begin{array}{l}\text { Physical } \\
\text { removal for } \\
\text { on-site off- } \\
\text { site } \\
\text { treatment } \\
\text { and/or } \\
\text { disposal }\end{array}$ & $\begin{array}{l}\text { High - } \\
\text { removes } \\
\text { residuals } \\
\text { down to } 10 \\
\text { ppm }\end{array}$ & $\begin{array}{l}\text { Low - } \\
\text { readily } \\
\text { acceptable by } \\
\text { regulators }\end{array}$ & $\begin{array}{l}\text { Very low - } \\
\text { highway, } \\
\text { building, } \\
\text { depth, water } \\
\text { table are all } \\
\text { limitations }\end{array}$ & $\begin{array}{l}\text { High - } \\
\text { worker } \\
\text { exposure to } \\
\text { accidents, } \\
\text { PCBs }\end{array}$ & Very high & $\begin{array}{l}\text { High - } \\
\text { removes } \\
\text { residuals }\end{array}$ & $\begin{array}{l}\text { High - } \\
\text { removes } \\
\text { residuals }\end{array}$ & High & $\begin{array}{l}\text { Not } \\
\text { recommended } \\
\text { due to } \\
\text { extremely high } \\
\text { costs and risk to } \\
\text { workers during } \\
\text { implementation }\end{array}$ \\
\hline $\begin{array}{l}\text { Surfactan } \\
\text { ts/Co- } \\
\text { solvents }\end{array}$ & $\begin{array}{l}\text { Chemical } \\
\text { extraction }\end{array}$ & $\begin{array}{l}\text { Low to } \\
\text { medium } \\
\text { given low } \\
\text { permeability, } \\
\text { remaining } \\
\text { residuals, and } \\
\text { the need to } \\
\text { control and } \\
\text { recover all } \\
\text { injected } \\
\text { chemicals }\end{array}$ & $\begin{array}{l}\text { High - given } \\
\text { increased } \\
\text { contaminant } \\
\text { mobility and } \\
\text { need to } \\
\text { document } \\
100 \% \\
\text { capture, } \\
\text { potential to } \\
\text { expand } \\
\text { source area }\end{array}$ & $\begin{array}{l}\text { Low - given } \\
\text { low } \\
\text { permeability } \\
\text {, tight well } \\
\text { spacing } \\
\text { requirement } \\
\text { s, and } \\
\text { difficult } \\
\text { recovery }\end{array}$ & $\begin{array}{l}\text { Medium - } \\
\text { the recovery } \\
\text { requires } \\
\text { handling of } \\
\text { high } \\
\text { concentration } \\
\text { s of PCB } \\
\text { waste }\end{array}$ & $\begin{array}{l}\text { High - } \\
\text { secondary } \\
\text { waste } \\
\text { volumes } \\
\text { high }\end{array}$ & $\begin{array}{l}\text { Low - } \\
\text { perceived } \\
\text { inability to } \\
\text { control } \\
\text { process, } \\
\text { spread of } \\
\text { contamination } \\
\text { and secondary } \\
\text { waste issues }\end{array}$ & $\begin{array}{l}\text { Low to } \\
\text { medium } \\
\text { due to } \\
\text { residual } \\
\text { contamin } \\
\text { ation }\end{array}$ & $\begin{array}{l}\text { Medium to } \\
\text { low - } \\
\text { given } \\
\text { difficulty } \\
\text { with } \\
\text { permeabili } \\
\text { ty }\end{array}$ & $\begin{array}{l}\text { Not } \\
\text { recommended } \\
\text { given } \\
\text { implementation } \\
\text { risks }\end{array}$ \\
\hline $\begin{array}{l}\text { Thermal } \\
\text { Removal }\end{array}$ & $\begin{array}{l}\text { Steam } \\
\text { stripping }\end{array}$ & $\begin{array}{l}\text { Low to } \\
\text { medium } \\
\text { given low } \\
\text { permeability } \\
\text { and residuals } \\
\text { left in place }\end{array}$ & $\begin{array}{l}\text { High - } \\
\text { increases } \\
\text { mobility of } \\
\text { PCBs that } \\
\text { may lead to } \\
\text { spread of } \\
\text { contaminatio } \\
n\end{array}$ & $\begin{array}{l}\text { Low - due } \\
\text { to lack of } \\
\text { access }\end{array}$ & $\begin{array}{l}\text { Medium to } \\
\text { high - } \\
\text { recovery } \\
\text { requires } \\
\text { handling of } \\
\text { high } \\
\text { concentration } \\
\text { s of PCB } \\
\text { waste along } \\
\text { with high } \\
\text { temperatures } \\
\text { and pressures } \\
\text { potentially } \\
\text { under } \\
\text { buildings }\end{array}$ & $\begin{array}{l}\text { High-due } \\
\text { to energy } \\
\text { costs and } \\
\text { secondary } \\
\text { waste } \\
\text { volumes }\end{array}$ & $\begin{array}{l}\text { Low - } \\
\text { potential to } \\
\text { lose control } \\
\text { may be } \\
\text { unacceptable }\end{array}$ & $\begin{array}{l}\text { Low to } \\
\text { medium } \\
\text { due to } \\
\text { residual } \\
\text { contamin } \\
\text { ation }\end{array}$ & $\begin{array}{l}\text { Low to } \\
\text { medium } \\
\text { due to } \\
\text { difficulty } \\
\text { with } \\
\text { permeabili } \\
\text { ty }\end{array}$ & $\begin{array}{l}\text { Not } \\
\text { recommended - } \\
\text { high cost, } \\
\text { difficult } \\
\text { implementation, } \\
\text { high risk. } \\
\text { Could be used } \\
\text { in conjunction } \\
\text { with other } \\
\text { strategies }\end{array}$ \\
\hline
\end{tabular}


WSRC-RP-2003-00276

page 32 of 53

\begin{tabular}{|c|c|c|c|c|c|c|c|c|c|c|}
\hline Approach & Strategy & $\begin{array}{l}\text { Effectivenes } \\
\text { s* }^{*}\end{array}$ & $\begin{array}{l}\text { Permitting } \\
\text { Risk }\end{array}$ & $\begin{array}{l}\text { Implement- } \\
\text { ability }\end{array}$ & $\begin{array}{l}\text { Health and } \\
\text { Safety Issues }\end{array}$ & Cost* & $\begin{array}{l}\text { Public } \\
\text { Acceptability } \\
\text { (Stakeholder) }\end{array}$ & $\begin{array}{l}\text { Long- } \\
\text { term } \\
\text { Liability } \\
\end{array}$ & $\begin{array}{l}\text { Technical } \\
\text { Maturity }\end{array}$ & Overall \\
\hline $\begin{array}{l}\text { Free } \\
\text { Product } \\
\text { Removal }\end{array}$ & $\begin{array}{l}\text { Source } \\
\text { reduction } \\
\text { through } \\
\text { pumping of } \\
\text { source oil }\end{array}$ & $\begin{array}{l}\text { Low - given } \\
\text { large residual } \\
\text { and } \\
\text { unreliable } \\
\text { recovery }\end{array}$ & $\begin{array}{l}\text { High - } \\
\text { limited } \\
\text { effectiveness } \\
\text { on source }\end{array}$ & $\begin{array}{l}\text { Medium - } \\
\text { difficult to } \\
\text { know where } \\
\text { to drill }\end{array}$ & $\begin{array}{l}\text { Medium - } \\
\text { handling } \\
\text { PCB oils }\end{array}$ & Low & $\begin{array}{l}\text { Low - limited } \\
\text { effectiveness }\end{array}$ & $\begin{array}{l}\text { Low - } \\
\text { high due } \\
\text { to } \\
\text { residual } \\
\text { contamin } \\
\text { ation }\end{array}$ & $\begin{array}{l}\text { Medium - } \\
\text { especially } \\
\text { for fine } \\
\text { grained } \\
\text { materials }\end{array}$ & $\begin{array}{l}\text { Not } \\
\text { recommended } \\
\text { but may be used } \\
\text { in conjunction } \\
\text { with other } \\
\text { approaches }\end{array}$ \\
\hline
\end{tabular}

$*$ Cost: low $<\$ 5$ million, moderate $>\$ 5-\$ 20$ million, high $>\$ 20-\$ 50$ million; very high $>\$ 50$ million 
WSRC-RP-2003-00276

page 33 of 53

\subsection{CONTINUED INVOLVEMENT}

Personnel at KCP will review this report and select their strategy for continuing to control PCB levels in the outfall. During the KCP strategy development period, the technical assistance team is available for general support (e.g., clarification of initial recommendations, and assistance in addressing issues or overcoming barriers encountered). Depending on the KCP selected course of action, the technical assistance team can provide further detailed assistance and, if needed, return to the site for specific support actions. Examples of additional assistance that might be provided include drafting sampling strategies and plans, developing technical functional requirements, and providing implementation assistance. The specific type(s) of technical assistance desired will be proposed by KCP following their strategy development process. The technical assistance activities will then will be formalized and approved by DOE Headquarter.

As part of this sustained technical assistance effort, there may be a need for routine communications in the way of conference calls, one-on-one conversations, and potential site visits. Members of the technical assistance team will continue to be available for consultation. Importantly, the assistance effort is limited to technical support - KCP technical assistance is not intended as staff augmentation and does not replace the need for local technical staff. The recommendations and supporting information developed by the team were developed rapidly, using a technical triage approach, and is based on a limited visit and rapid review of data and conditions. Thus, the results are recommendations to the local support staff and managers and $\mathrm{KCP}$ should not be bound by the recommendations coming from the technical assistance team but rather view them as a resource. 
WSRC-RP-2003-00276

page 34 of 53

\subsection{REFERENCES}

Aronstein and Rice, 1995, Biological and Integrated Chemical-Biological Treatment of PCB Congeners in Soil Sediment-Containing Systems, Journal of Chemical Technology and Biotechnology, 63 (4): 321-328 AUG 1995, John Wiley \& Sons Ltd, W Sussex.

Bleier, A. 1997. Evaluation of Final Waste Forms and Recommendations for Baseline Alternatives to Grout and Glass, ORNL/TM-13214.

Butcher, J. B., T. D. Gauthier, and E. A. Garvey. 1997. Use of historical PCB aroclor measurements: Hudson River fish data. Environmental Toxicology And Chemistry 16:1618-1623.

Cassidy et al., 2002, Combined chemical (ozone) and biological treatment of polychlorinated biphenyls (PCBs) adsorbed to sediments, Journal of Chemical Technology and Biotechnology, 77 (6): 663-670 JUN 2002, John Wiley \& Sons Ltd, W Sussex. Chiarenzelli et al., 2001, Combined steam distillation and electrochemical peroxidation (ECP) treatment of river sediment contaminated by PCBs, Chemosphere, 45 (8): 11591165 DEC 2001, Pergamon-Elsevier Science Ltd, Oxford.

Clancy, H., DARA SSF. Presentation made on July 17, 2002.

Cline, S.R. et al., Chemical Oxidation of Polychlorinated Biphenyls (PCBs) using Hydrogen Peroxide or Potassium Permanganate. Oak Ridge National Laboratory, Oak Ridge, TN.

Duffy et al., 2000, Wet peroxide oxidation of sediments contaminated with PCBs,

Environmental Science \& Technology, 34 (15): 3199-3204 AUG 1 2000, American Chemical Society, Washington.

EPA Method 1668, Revision A: Chlorinated Biphenyl Congeners in Water, Soil, Sediment, and Tissue by HRGC/HRMS. EPA-821-R-00-002, December 1999.

EPA, 1999. Stormwater Technology Fact Sheet: Modular Treatment Systems. EPA 832-F-99044, U. S. Environmental Protection Agency, Office of Water, Washington DC.

Focht, D. 1993. Microbial Degradation of Chlorinated Biphenyls. Chapter 9 in Soil Biochemistry Vol. 18, Eds. Bollag, J. and Stotzky, G., Marcel Dekker, Inc. New York, New York.

Hazen, T. C. 1997. Bioremediation. In: Microbiology of the Terrestrial Subsurface (Eds) P. Amy and D. Haldeman, p 247-266. CRC Press, Boca Raton.

Heiser, J. H., M. North-Abbott, T. Sullivan, H. Ludewig, K. Manchester, Marek Zaluski, Gail Penny, and Jim Brower, 1999. Viscous Liquid Barrier Demonstration at the Brookhaven National Laboratory LINAC Isotope Producer, BNL-67336, Brookhaven National Laboratory.

Hickey, W. 1999. Transformations and Fate of PCBs on Soil and Sediment. Chapter 9 in Bioremediation of Contaminated Soils, Agronomy Monograph No. 37, American Society of Agronomy, Crop Science Society of America, Soil Science Society of America.

Kalb, P. D., 1991, Polyethylene Encapsulation of Nitrate Salt Wastes: Waste Form Stability, Process Scale-up, and Economics, Technology Status Tropical Report, BNL—52293, Brookhaven National Lab., Upton, NY, 1991.

Langton, Christine A., Roger D. Spence, and John Barton, 2002, State of the Art Report on High- Level Waste Tank Closure, WSRCTR-2001-00359, Rev. 0, 2002.

Leudtke, N. A. Data Verification and Validation. Presentation made on July 17, 2002 to SCFA Technical Assistance team. Maio, Vincent, 1998, Mixed Waste Area Approach for Developing Alternative Stabilization Technologies for Fly Ash and Salt Containing Mixed Waste, WM'98 Proceedings, pp 779-787, vol 779, 1998. 
WSRC-RP-2003-00276

page 35 of 53

Mattus, A.J., et al. 1994. A Low-Temperature Process for the Denitration of Hanford SingleShell Tank, Nitrate-Based Waste Utilizing the Nitrate to Ammonia and Ceramic (NAC) Process, ORNL/TM-12245.

Mattus, C. H., 1998, Demonstration of Macroencapsulation of Mixed Waste Debris Using Sulfur Polymer Cement, ORNL/TM-13575, 1998.

Mattus, C. H. and A. J. Mattus, 1994, Evaluation of Sulfur Polymer Cement as a Waste Form for the Immobilization of Low-Level Radioactive or Mixed Waste, ORNL/TM-12657, 1994. LBNL-51389

ORNL, 1998. Natural attenuation of chlorinated solvents in groundwater at the Department of Energy, Kansas City Plant, Indian Creek groundwater flow system.

Price, T. Disposal Area Remedial Action Solids Storage Unit: Analytical Results Compared to Process Waste LDR Limits, Soil Waste LDR Limits, and Disposal Facility WAC Documents. Presentation made on July 17, 2002 to SCFA Technical Assistance team.

Rogers, J. D., N. M. Duteau, et al. (1999). "Sequential anaerobic/aerobic treatment of polychlorinated biphenyls in soil microcosms." Abstracts of the General Meeting of the American Society for Microbiology 99: 540.

Sedlak and Andren, 1994, The Effect of Sorption on the Oxidation of Polychlorinated-biphenyls (PCBS) by Hydroxyl Radical, Water Research, 28 (5): 1207-1215 MAY 1994, Pergamon- Elsevier Science Ltd, Oxford.

Siemer, D. D., D. M. Roy, M. W. Grutzeck, M. L. D. Gouger, and B. E. Scheetz, 1996, PCT Leach Tests of Hot Isostatic Pressed (HIPped) Zeolitic Concretes, Scientific Basis for Nuclear Waste Management, Materials Research Society Symposium Proceedings 465, pp 303-309, W. J. Gray and I. R. Triay, Eds., 1996, Materials Research Society.

Siemer, D. D., M. W. Grutzeck, D. M. Roy, and B. E. Scheetz, 1998, Zeolite Waste Forms Synthesized from Sodium Bearing Waste and MetaKaolinite, Proceedings of WM '98, March 1-5, 1998, Tucson, Arizona, in Session 36 on CD-ROM published by WM Symposia, Inc.

Spence, R.D., et al. 1990. Immobilization of Volatile Organic Compounds in Commercial Cement-Based Waste Forms, ORNL/TM-11251.

Whang, J. M., 1995. Chemical Based Barrier Materials. In Assessment of Barrier Containment Technologies: A Comprehensive Treatment for Environmental Remediation Applications, R. R. Rumer and J. K. Mitchel eds., U.S.DOE, Washington D.C. 
WSRC-RP-2003-00276

Page 36 of 53

\section{APPENDIX A \\ Members of the Technical Assistance Team}

Brian B. Looney

Senior Fellow Research Engineer

Savannah River Technology Center

Building 773-42A, Aiken, SC

(803) 7253692 or (803) 7252418

brian02.looney@srs.gov

\section{Areas of Expertise:}

Dr. Looney is a fellow research engineer at the Savannah River Technology Center. In this position for the past 15 years, he has coordinated development and deployment of environmental characterization and clean-up technologies. Dr. Looney has successfully performed environmental projects on a wide range of topics. For example, he was principal investigator responsible for the first large scale application of horizontal drilling to environmental remediation. Other successful research efforts include: soil gas survey techniques for hazardous waste sites, barometric pumping for vadose zone clean up. gas phase nutrient addition to stimulate bioremediation, and various topics associated with modeling and risk assessment. Dr. Looney currently holds five U.S. and one foreign patent for environmental technologies. Most of these are licensed to environmental engineering companies and are in use throughout the U.S. Dr. Looney, in collaboration with others, contributed to recent field studies at the Mayak Site (a former nuclear production facility) in Russia. Recently, Dr. Looney co-edited the book "Vadose Zone Science and Technology Solutions". He also led the successful efforts to redefine the Subsurface Contaminants Focus Area technical program in terms of technical targets within which R\&D programs could be developed.

\section{Terry H. Hazen}

Head of Environmental Remediation Technology Program

Lawrence Berkeley National Laboratory

Earth Sciences Division, MS 70A-3117

Berkeley, CA

(510) 486-6223

tchazen@1bl.gov

\section{Areas of Expertise:}

Dr. Hazen's area of specialty is environmental microbiology, especially as it relates to bioremediation. His current research is focused on aerobic bioremediation of landfills, PAH contaminated soil, solvent contaminated soil and groundwater, and actinide biogeochemistry. Since early 1998, Dr. Hazen has been Head of the Microbial Ecology and Environmental Engineering Department and Lead Scientist for the Environmental Remediation Technology Program in the LBNL Earth Sciences Division. Since September 1999 he has also been head of the Center for Environmental Biotechnology. He is a fellow of the American Academy of Microbiology and has authored more than 151 scientific publications, not including more than 390 abstracts and chapters in several books. He has also given more than 670 scientific 
presentations, $75 \%$ of them invited. Dr. Hazen received the 1995 R\&D 100 Award, 1996 R\&D 100 Award, and the 1996 Federal Laboratory Consortium Excellence in Technology Transfer for bioremediation technologies. He has patents on 5 bioremediation processes that are being used in 15 states; these technologies have been licensed to more than 30 companies. Dr. Hazen has acted as an expert reviewer for 25 different scientific journals and 14 federal research granting agencies. He has supervised and consulted on the implementation of bioremediation at more than 50 sites in several countries. He is currently the LBNL representative to the DOE EM50 Strategic Lab Council, the DOE Natural and Accelerated Bioremediation Research Program Field Research Center, the EM50 Subsurface Contaminant Focus Area Lead Lab POC, and the EM50 lead for LBNL. He was recently appointed to the United Nations Global Water Quality Task Force, one of only two US scientists.

\section{David Eaton}

Regulatory Specialist

Idaho Environmental and Engineering National Laboratory

PO Box 1625

Idaho Falls, ID 83415-3875

(208) 526-7002

\section{Areas of Expertise:}

David L. Eaton is a Regulatory Specialist with the Idaho National Engineering \& Environmental Laboratory. He has 29 years of experience in the environmental field. He has worked in private industry, state government, EPA, and is now working at the INEEL to facilitate the development and testing of mixed waste treatment technologies. He chairs a number of working groups between DOE, DOE sites, EPA, and appropriate state regulatory agencies seeking to resolve regulatory issues related to the treatment of mixed waste. He received his B.S. in Chemistry from the South Dakota School of Mines \& Technology and his M.S. from the University of Idaho in Environmental Engineering. 
WSRC-RP-2003-00276

page 38 of 53

\section{APPENDIX B \\ KCP ER Remediation Strategy Document - 2002}

\section{KANSAS CITY PLANT - ENVIRONMENTAL RESTORATION REMEDIATION STRATEGY December 2002}

\section{EXISTING CONDITIONS}

\section{Groundwater and Soil}

Alluvial groundwater at the Kansas City Plant (KCP) is contaminated with up to several thousand parts-per-million of chlorinated solvents along with minor amounts of other substances including Polychlorinated biphenyl's (PCBs). Alluvial groundwater also contains naturally occurring arsenic at levels exceeding primary drinking water standards (i.e., maximum contaminant levels, MCLs). The aquifer also exhibits total dissolved solids in excess of drinking water standards. The KCP is regulated under the Resource Conservation and Recovery Act (RCRA) and implements corrective action pursuant to requirements of a post closure permit issued by the Missouri Department of Natural Resources (MDNR). The permit requires that groundwater be restored to MCLs or other state or federal risk based concentrations for use as a drinking water source. Arsenic exceeds MCLs naturally while the permit requires that groundwater be "restored" to MCLs.

Contaminated groundwater is currently addressed by the operation of ten groundwater extraction wells that inhibit off-site migration to potential off-site receptors. Building footing tile drains capture groundwater from under many KCP buildings augmenting containment. An in-situ permeable reactive barrier (iron wall) was installed in 1998 to contain that portion of the plume discharging to the Blue River. However the barrier does not treat contaminants to the extent necessary. Groundwater pumping in the area of the barrier resumed upon regulator insistence in June of 2000 to address the iron wall's inability to effectively treat contaminated groundwater. The extent to which containment is needed is in doubt because contaminants have not been detected in the Blue River despite the fact that the plume has reached the river. Recent research has demonstrated that anaerobic VOC laden contaminant plumes like those at the KCP are attenuated naturally when they discharge to a surface water body.

The KCP's RCRA post closure permit requires that the groundwater contaminant plume be contained, that hot spots of contamination be addressed and that drinking water standards or equivalent risk based levels predicated on using the aquifer as a drinking water source be met in selected wells.

The KCP remains in compliance with the RCRA post closure permit and has completed all corrective actions to the satisfaction of state and federal regulatory authorities. All field investigations are complete with a final corrective action decision pending at one Solid Waste Management Unit (SWMU). Regulatory authorities at all other SWMUs have selected final remedies. 
Selected remedial alternatives under RCRA corrective action for soil have been primarily addressed through institutional controls. Soil remediation was historically conducted during the investigatory phase of the RCRA corrective action process as Interim Measures and centered on removal of accessible hot spot contaminant areas in the vadose zone. Remaining, less accessible, areas of soil contamination were left in place to be addressed through institutional controls. The lone remaining SWMU without a final selected remedy (SWMU 43 - 95th Terrace (which includes Outfall 002)) exhibits PCB contaminated soil and sediments at and/or near an off site receptor (Indian Creek). The $95^{\text {th }}$ Terrace risk assessment identified human health risks associated with consumption of fish and dermal contact with sediments at the stormwater Outfall 002 raceway.

\section{Stormwater}

Single pass non-contact cooling water and rain event run-off discharge through four National Pollutant Discharge Elimination System (NPDES) permitted outfalls numbered 001 through 004. Detectable levels of chlorinated solvents and/or PCBs have been detected in these outfalls. Periodic monitoring of the four outfalls and six surface water sites on the Blue River and Indian Creek is conducted. Weekly monitoring of Outfall 002 for PCBs and solvents is also required primarily as a result of PCB contamination noted above. Extensive measures to eliminate contaminants in surface water have been successful overall with only sporadic detections still present in outfall discharges.

The current NPDES permit contained an interim PCB limit of one part per billion (ppb) with a final effluent limit of $0.5 \mathrm{ppb}$ effective November 6, 2002. Historically, PCB discharges in stormwater have been regulated at $1.0 \mathrm{ppb}$. Despite the best efforts of the KCP to comply with the final effluent limit of $0.5 \mathrm{ppb}$, based on trend analysis of recent data, the final limit will likely be exceeded $8-10$ times per year. MDNR and KCP representatives have met on several occasions to determine a reasonable course of action to maintain permit compliance. As suggested by MDNR, the KCP has previously submitted a permit limit recalculation request, however, MDNR has recently denied this request. KCP and MDNR representatives have determined that a Settlement Agreement is now the best course of action to ensure ongoing compliance with the NPDES Permit while the KCP continues to attempt to reduce PCB levels in stormwater discharges from the facility.

The Settlement Agreement period will be for one to two years during which time the final limit will be in effect but not enforced as long as compliance with the Settlement Agreement is maintained. Specific corrective actions will be incorporated into the Settlement Agreement.

Recently, VOCs have been detected in three of the four regulated outfalls (Outfalls 002, 003 and 004). The NPDES Permit only requires that the KCP monitor for VOCs, therefore, there is no current permit limit. The KCP has notified MDNR that these compounds have been detected and the state has informed KCP representatives that VOCs will be regulated in the 2004 version of the permit. Recently, Outfall 003 was lined to address PCBs detected in this outfall. Lining was also intended to address VOCs in this outfall and has successfully addressed this issue as no VOCs have been detected since completion of the lining project. Outfall 004 is scheduled to be lined using EM funds, however, due to significant cuts in the EM program it is possible that remediation of VOCs in this outfall may be delayed due to a lack of funds. Outfall 002 has only 
WSRC-RP-2003-00276

page 40 of 53

recently began to detect VOCs in the discharge and initial efforts to identify the source of this contamination are in the preliminary stages.

\section{PROBLEM DESCRIPTION}

\section{Groundwater}

A problem exists in that the combination of pump and treat technology, the nature and distribution of contamination in the subsurface environment and the conservative groundwater clean up goals effectively result in an agreement to operate the pump and treat system in perpetuity. Because of the costs associated with such a long-term commitment, the KCP remediation strategy emphasizes assessment of environmental risks as allowed by state and/or federal regulation along with cost-effectiveness. By including these factors into long-term planning, the KCP's Environmental Restoration program can ultimately be brought to a cost-effective and environmentally safe conclusion while maintaining regulatory compliance at all times.

\section{Soil, Sediment, Surface Water}

A second problem exists in that institutional controls likely to be proposed for soil, sediment and surface water at the 002 Outfall as a part of the $95^{\text {th }}$ Terrace site acknowledge a risk to human health from the consumption of fish in the area and exposure to sediments and surface water in the outfall 002 raceway.

\section{CONSIDERATIONS OF ENVIRONMENTAL RISK}

\section{Groundwater}

A formal Alternate Concentration Limit (ACL) petition was prepared and submitted to EPA and MDNR in August 1995 which proposed to modify the stringent groundwater cleanup levels based upon recognition and evaluation of a number of risk considerations.

These risk considerations, as compiled from various project reports, reveal the following facts:

1. The alluvial aquifer at the KCP has a relatively low-yield, no known uses, and no projected uses. The aquifer matrix is clayey-silt. The resulting low recharge and low flow rate have led to the establishment of reducing conditions in the aquifer. These reducing conditions have led to the release of naturally-occurring iron, manganese, and arsenic, all of which exceed either secondary (iron and manganese) or primary (arsenic) drinking water standards rendering them unusable as a drinking water source. MDNR, in the KCP's post closure permit, prohibits the use of the aquifer as a source of drinking water.

2. The bedrock aquifer at the KCP is not threatened by contamination in the alluvium. At least thirty feet of shale separate the uppermost aquifer from the next existing water-bearing unit (Hepler Sandstone). The Hepler Sandstone produces only minor amounts of water negating any beneficial uses.

3. A detailed study of the KCP's impact to surrounding streams (i.e., potential off-site receptors) indicated that the quantity of contaminated water that could be discharged to 
the surrounding streams is so low that it would not be detectable under any flow conditions. Subsequent research conducted at other sites has now shown that when anaerobic VOC laden contaminant plumes discharge to surface water bodies that the oxidizing conditions encountered result in rapid degradation of the contaminant. Thus the amount of contamination assumed to enter the river in the ACL petition was too high, and there is actually a greater safety factor than the original petition asserted.

4. An evaluation of EPA's guidance for successfully establishing an ACL showed that such an approach is feasible. That evaluation further noted that it was necessary that site investigations be complete and that the plume is no longer growing, or, if it is discharging to surface water, that the contaminants not be detectable in the stream.

The state of Missouri responded to the ACL petition in comments dated November 25, 1996. Responses to these comments were prepared but were never transmitted to MDNR. At the request of DOE, no further activity has occurred on the petition.

Missouri Senate Bill 334 was signed into law in 1999. It tasks the Missouri Clean Water Commission to establish procedures for determining whether remediation of groundwater based on risk to human health and the environment is appropriate for any particular site. Specific items that must be accounted for in making such a determination include the following;

- Impacts of the contaminants on any public or private drinking water supply

- The likelihood that the contaminated groundwater could be used as a drinking water supply

- Impact on protected water bodies

- Appropriateness of other methods to remediate groundwater contaminants

Regulations were drafted by the state of Missouri to implement risk-based groundwater cleanups in 2001 then rescinded in 2002, in part due to an excessive number of stakeholder comments. The rule, as originally proposed, was applicable to the KCP based on review of initial drafts. Document submissions were required in the regulation and included a Site Characterization Report, Exposure Pathway Assessment Report, Risk Characterization and Clean up Levels Report and a Risk Based Groundwater Remediation Plan. Contaminant containment and/or source removal may have been required by the rule in order to be considered complete. The nature, timing and need for such action being unknown. Regulations are currently being redrafted by a team of stakeholders consisting of regulatory authorities along with industry and environmental groups. It is expected to be re-proposed in the near future.

\section{KCP LONG-TERM ENVIRONMENTAL STRATEGY}

The KCP long-term environmental strategy is based on the following beliefs:

1. Pump and treat technology will not restore the contaminated aquifer to the cleanup goals established under the RCRA Post- Closure permit.

2. Perpetual operation of a pump and treat system is not cost-effective for the long-term although regulatory compliance is maintained. 
3. The current groundwater pumping system effectively contains contamination and addresses MDNR permit requirements regarding contamination.

4. Operation of an in-situ iron wall effectively reduces a majority of dissolved contaminant mass flowing into the Blue River. A modification to the barrier or the use of a complimentary technology to capture the remaining portion of the plume that does not pass through the iron wall should be implemented if technically and economically feasible. The pump and treat system remains operational at regulator insistence rendering the wall ineffective.

5. Risk based groundwater clean up is feasible for each of the contaminant plumes under treatment. Missouri risk based groundwater clean up regulations to be re-proposed in the near future are preferred, as they would globally address state programmatic concerns whereas an ACL petition under RCRA would satisfy concerns only under that program. State regulations are to be re-proposed in 2003 with required document preparation, review, negotiation and approvals taking another two to three years. Any risk-based approach must be acceptable from both a regulatory and public trust standpoint.

6. While not expected to provide noticeable benefits to achieve groundwater cleanup standards in the short-term, contaminant source area reduction should be pursued where treatment success is expected and impacted soils are accessible. This component should be pursued whether or not revised risk based standards are established for the facility. Source reduction and/or removal are specific tasks in the draft risk-based groundwater clean up regulations. Evaluation of source reduction technologies is also required by the RCRA Part B permit.

These beliefs are based on the following considerations:

The conceptual model for the KCP suggests that solvents exist in the subsurface as dense nonaqueous phase liquids (DNAPLs). Specifically, DNAPLs are trapped as discontinuous ganglia throughout source areas of contamination including, but not limited to, the TCE Still Area, the area adjacent to and within the main plant building between wells 184 and 192 (Old Plating Building degreaser location) and the Old Ponds in the area immediately north of the former North Lagoon. Areas of DNAPL are expected to provide a source of contamination to the groundwater for a considerable period of time. It is also concluded, because of the likely presence of DNAPL and the tortuous flow path for groundwater at the $\mathrm{KCP}$, that pump and treat is unlikely to significantly alter groundwater contaminant concentrations for an extensive period of time. Pump and treat systems are only capable of removing the contaminant mass that will dissolve into the groundwater as it passes through the area of DNAPL. Approximately 2627 pounds of VOCs have been removed from the alluvial aquifer since the installation of the groundwater pump and treat system in 1988. This cumulative mass removed is almost 10 times the amount of dissolved VOCs that remain in groundwater in the dissolved state. The fact that solvent mass continues to be removed (albeit at a very slow rate) and the dissolved mass of the contaminant plume remains steady suggests a source "feeding" the dissolved mass. That is, a DNAPL source. 
WSRC-RP-2003-00276

page 43 of 53

A further difficulty arises in that, although contaminant source locations are known, it is very difficult to quantify the amount of chlorinated solvent in source areas due to the heterogeneous distribution of DNAPL.

\section{It is unlikely that MDNR would approve a risk-based petition unless some source reduction at primary source areas has been attempted and/or achieved, a thought echoed in specific language in the KCP's post-closure permit.}

Source reduction can be achieved in three primary ways. The first is to pump the groundwater until contaminant levels in the source area production and monitoring wells show a clearly discernible decrease that persists even after the system has been turned off for several days. This approach will ultimately be successful, but based on analysis of the existing pump and treat system, will apparently require decades, if not longer, depending upon the quantity of solvent that is present.

The second approach is to implement some type of proven source treatment that would reduce contaminant concentrations in the source area wells more rapidly. Six-phase heating is a candidate technology though its effectiveness in the KCP subsurface environment is unknown. The depth of the contamination makes excavation and removal inherently expensive and may, in certain areas, risk the integrity of buildings, and of other structures and utilities. All source areas of contamination would need to be addressed to realize the benefits of such treatment.

A third approach encompasses the utilization of innovative, yet unproven technologies. The KCP continues to evaluate and support the development of new technologies at the site in order to implement an appropriate source area reduction technique.

To summarize the $\mathrm{KCP}$ remediation strategy encompasses the following:

- Address remediation of KCP groundwater based on risk following yet to be promulgated MDNR regulations that allow regulatory concerns to be addressed across programmatic lines, something unavailable with a RCRA ACL petition. Risk-based clean up standards are to be pursued with the expressed intent of eliminating or reducing the time required for the collection and treatment of contaminated groundwater.

- Continue operation of the next generation pump and treat system. Regulatory compliance with groundwater corrective action will be maintained allowing time for Missouri regulations to be promulgated. Document preparation, negotiation and approval in support of such a petition may take several years.

- Investigate cost and if feasible, implement effective options for increasing the effectiveness of the iron wall.

- Pursue use of natural attenuation by discharge to a surface water body as the means of final treatment. Pursue augmentation of the receiving stream reach as is practical and appropriate. Perform sufficient investigation to prove the hypothesis and incorporate into any risk based clean up proposal. 
WSRC-RP-2003-00276

page 44 of 53

- Pursue source reduction in primary source areas to provide a potential reduction in long-term stewardship (i.e., pump and treat) and enhance state requirements for source containment /reduction in draft risk based groundwater clean up regulations.

- If risk based petition is not agreeable to State/DOE/or public, continue operation of next generation pump and treat system as installed. Regulatory compliance is maintained.

\section{Surface Water, Sediment and Soil}

In order to appease potential regulatory concerns regarding PCB loading in the immediate area of Outfall 002 the following actions are to occur. Sampling of the discharge from the outfall will continue at the frequency prescribed in the existing NPDES permit. A sampling plan for fish tissue analysis will be devised and conducted beginning in 2003 with sampling to be repeated every two years for 6 years to document the effect of 002 storm sewer corrective actions already performed as well as those to be performed in the future. An annual inspection of the sewer will also be conducted during this six year period. Fish tissue sampling is expected to show a decrease from the last sampling conducted in 1997. The 002 Outfall will be redesigned to prohibit access to contaminated materials. Bank sampling will occur to confirm that PCB contamination is limited to the outfall area. This information will be conveyed to the regulatory authorities in charge of NPDES permitting to help placate concerns they may have regarding the $95^{\text {th }}$ Terrace (Outfall 002) risk assessment. 
WSRC-RP-2003-00276

page 45 of 53

\section{APPENDIX C \\ Delaware Estuary Alert}

This document can be found at http://www.lfr.com/news/regupdate/regupdate018.htm

Regulatory Alert

Delaware River Basin Commission PCB Monitoring Requirements

The Delaware River Basin Commission (DRBC), the States of New Jersey and Delaware, the Commonwealth of Pennsylvania, and the United States Environmental Protection Agency (US EPA) are currently involved in a cooperative effort to control the discharge of toxic substances that could impact human and aquatic life in the tidal portion of the Delaware River from Trenton, New Jersey to the Delaware Bay.

Recently the DRBC completed a study of the loadings of polychlorinated biphenyls (PCBs) to the estuary from point sources and tributaries. A copy of the report is available at the DRBC website here for the monitoring report. Follow-up recommendations of the study included additional monitoring of municipal and industrial point sources for PCBs using low level, congener specific analytical methods. These data will be used to develop PCB loadings to the estuary and to prioritize sources for further characterization.

Earlier this year, the DRBC sent out notices to more than 100 municipal and industrial National Pollutant Discharge Elimination Systems (NPDES) permittees that discharge to the Delaware Estuary. The notices stated the specific requirements of the PCB monitoring program as well as the deadline for submitting the monitoring data by January 31, 2001. Sampling is to be conducted during both dry weather and wet weather monitoring periods. During wet weather monitoring periods, flow proportional sampling is required. The number of samples required for analysis is dependent on the number of discharge points at the permitted facility. The following is a typical listing of the specific monitoring requirements.

Dry Weather Monitoring -Sampling Requirements

1.A sample should be collected at the permitted discharge when no rainfall had occurred within the previous 72 hours and during periods representative of normal facility operation.

2.Wastewater samples shall consist of a 24-hour composite sample if discharge is continuous or, if the discharge is non-continuous, the composite sample shall consist of aliquots collected over the duration of the discharge.

3.Each sample shall be analyzed for 81 PCB congeners using methods with a detection limit of 0.5 nanograms per liter.

Wet Weather Monitoring - Sampling Requirements

1.All samples shall be collected from the discharge resulting from a storm event that is greater than 0.1 inches in magnitude and that occurs at least 72 hours from the previously

measurable storm event. 
WSRC-RP-2003-00276

page 46 of 53

2.Except as specified in Item 3 below, all storm water samples shall consist of samples collected by one or more of the following methods:

Constant Time - Volume proportional to flow increment

Constant Time - Volume proportional to flow rate

Constant Volume - Time proportional to flow volume increment

3.For discharges from holding ponds or other impoundments with a retention period greater than 24 hours, a minimum of one grab sample may be taken.

4.Each sample shall be analyzed for $81 \mathrm{PCB}$ congeners using methods with a detection limit of 0.5 nanograms per liter.

LFR has extensive experience in storm water and wastewater sampling and is familiar with the requirements of the DRBC for this particular study. For more information about the DRBC PCB monitoring program or if you would like to request a meeting at your facility, call LFR at 908526-1000 and ask to speak with Michael Weaver (ext. 464).

Michael Weaver is Manager, Site Assessment and Remediation Group in LFR's Raritan office. The group has been providing storm water and wastewater sampling services under the NPDES program to private and public sector clients in the New Jersey/Pennsylvania area for the past 30 years.

Information on this PCB monitoring program can also be found at the DRBC website.

Your comments, suggestions, and questions are encouraged. Correspondence should be sent to LFR via our "Information" button on the left.

LFR Regulatory New is published periodically with a goal of bringing lfr.com site visitors environmental news and regulatory updates. Great care is taken to ensure that the information provided is accurate and correct. However, discrepancies, omissions, or differences of opinion may occur. The information is gleaned from a number of sources within the public domain including regulatory agency communiqués, press releases, and environmental industry-related publications. The information cannot be regarded as technical or legal advice. The ultimate use of this information is the sole responsibility of the reader and not the responsibility of LFR, its parents and associated companies, editors, or contributors. John C. Blasco, Regulatory affairs Manager at LFR is the editor of Regulatory News.

Corporate Headquarters • 1900 Powell St., 12th Floor • Emeryville, CA 94608-1827•

800.320 .1028 
WSRC-RP-2003-00276

page 47 of 53

\section{APPENDIX D \\ List of Laboratories}

This document can be found at http://www.state.nj.us/drbc/PCB lablist.htm

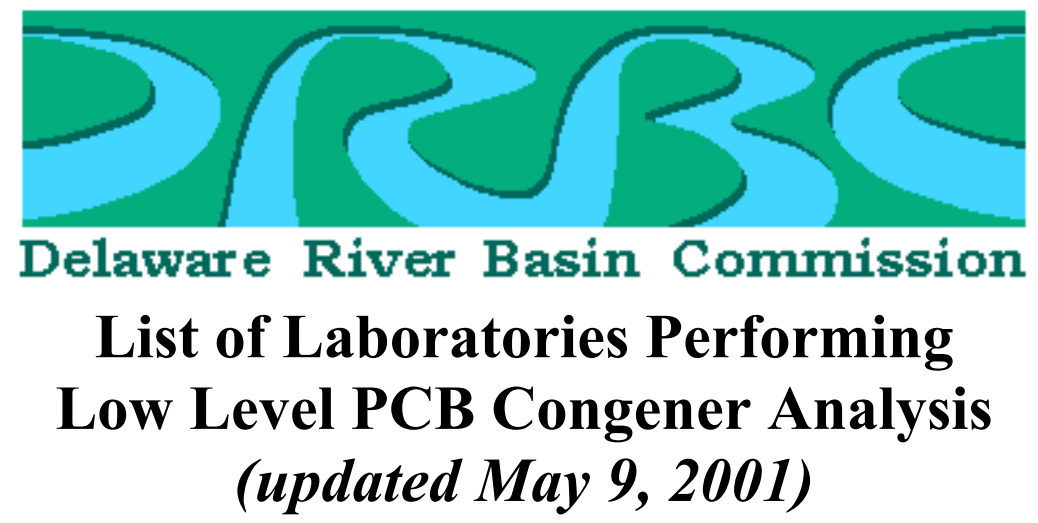

\section{Alta Analytical}

5070 Robert J. Matthews Pkwy, Suite 2

Eldorado Hills, CA 95630

Contact: William Luksemburg

Phone: (916) 933-1640

Fax: (916) 933-0940

Axys Analytical Services Ltd.

P.O. Box 2219

2045 Mills Road West

Sidney, British Columbia

CANADA V8L358

Phone: (250) 656-0881

Fax: (250) 656-4511

Battelle Ocean Sciences

397 Washington Street

Duxbury, MA 02332

Contact: Gregory Durell

Phone: (781) 952-5200

Fax: (781) 952-5221

E-mail: durell@,battelle.org

Columbia Analytical Services

1317 S. $13^{\text {th }}$ Avenue

Kelso, WA 98626-2845

Phone: (360) 577-7222

Eviro-Test Laboratories

$993667^{\text {th }}$ Avenue

Edmonton, Alberta

CANADA T6EOP5
Severn Trent Laboratory-Burlington

208 South Park Drive, Suite 1

Colchester, VT 05446

Contact: Jim Madison

Phone: (802) 655-1203

Fax: (802) 655-1248

E-mail: jmadison@stl-inc.com

Severn Trent Laboratory-Knoxville

5815 Middlebrook Pike

Knoxville, TN 37921

Contact: David I. Thal

Phone: (865) 291-3072

Fax: (865) 584-4315

E-mail: dthal@stl-inc.com

Severn Trent Laboratory-West Sacramento

880 Riverside Parkway

West Sacramento, CA 95605

Contact: Patrick Rainey

Phone: (916) 373-5600

Fax: (916) 371-8420

E-mail: prainey@stl-inc.com

Southwest Research Institute 6220 Culebra Rd.

San Antonio, TX 78238

Contact: Mike Dammon

Phone: (210) 522-5428

TDI-Brooks International, Inc.

1902 Pinon

College Station, TX, 77845

Contact: James M. Brooks 
WSRC-RP-2003-00276

page 48 of 53

Contact: Dr. Birkholz

Phone: (780) 413-5203

E-mail: deib@envirotest.com

Lancaster Laboratories

P.O. Box 12425

2425 New Holland Pike

Lancaster, Pa 17605-2425

Contact: Donald Nazario

Phone (717) 6562308

Fax (717) 656-9957

E-mail: djnazario@lancasterlabs.com

Midwest Research Institute

425 Volker Boulevard

Kansas City, MO 64110

Contact: Kathy Boggess or Vincy Abraham

Phone: (816) 753-7600 ext. 1134

Fax: (816) 753-8420

\section{Pace Analytical Services}

1700 Elm Street

Minneapolis, MN 55414

Contact: Chuck Sueper

Phone: (612) 607-6387

\section{Pacific Analytical}

6349 Pasco del Lago, Suite 102

Carlesbed, CA 92008

Contact: Bruce Colby

Phone: (760) 438-3100

Paradigm Analytical Laboratories, Inc.

2627 Northchase Parkway SE

Wilmington, NC 28405

Contact: Matthew Burns

Phone: (919) 639-7303

Fax: (919) 639-3152

E-mail: mattburns@earthlink.net
Phone: (409) 696-3634

Fax: (409) 696-5168

Texas A\&M Research Foundation

Geochemical \& Environmental Research Group

833 Graham Road

College Station, TX 77845

Contact: Mahlon Kennicutt

Phone: (409) 862-2323

Fax: (409) 862-2361

Triangle Laboratories

Alston Technical Park

801 Capitola Drive, Suite 10

Research Triangle Park, NC 27713

Contact: Frank Stevens

Phone: (919) 544-5729 ext. 258

\section{Woods Hole Group Environmental}

Laboratories

375 Paramount Drive, Suite B

Raynham, MA 02767

Contact: Helder Costa

Phone: (508) 822-9300

Fax: (508) 822-3288

Wright State University

Contact: Thomas Tieman

Phone: (513) 873-2202

Fax: (513) 873-3807 


\section{APPENDIX E \\ One Example of a Modular Wetland Treatment System}

Note: Many variants are possible. An isolated, or "lined" system such as this would minimize any considerations about impacts to nearby berms. An unlined system has advantages of reducing overall volume of discharged directly into surface water (the ultimate goal of the effort) and raising distal groundwater levels slowing the flow of groundwater under the facility.

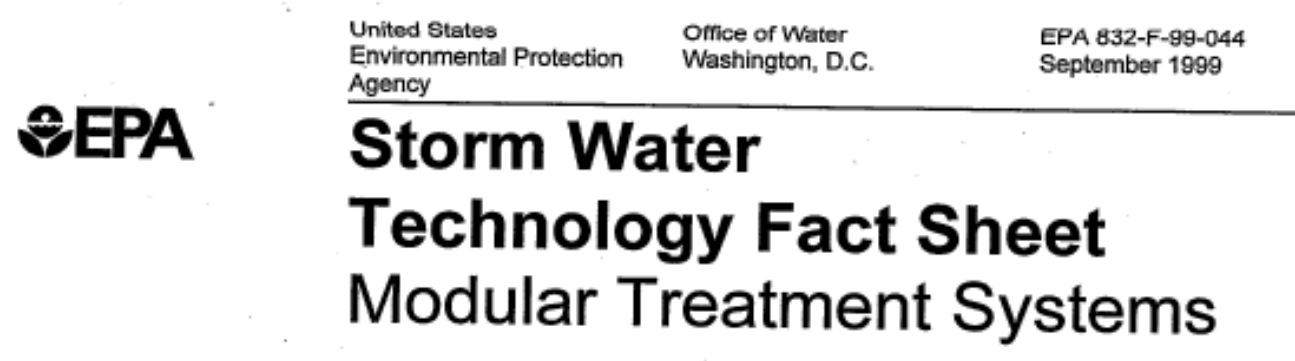

\section{DESCRIPTION}

This fact sheet describes modular systems for treating storm water. One of the primary modular storm water treatment systems currently on the market is the Storm Treat ${ }^{\mathrm{TM}}$ System, or STS. The STS, which was developed in 1994 , is a storm water treatment technology consisting of a series of sedimentation chambers and constructed wetlands. These wetlands are contained within a modular, 2.9-meter ( 9.5 feet) diameter recycled-polyethylene tank. The STS can be applied in many different scenarios, ranging from residential areas to most industrial parks, but should not be used in extremely polluted areas, such as directly in wastewater streams. Figure 1 is a diagram of the STS. The STS works as follows: influent is piped into the unit's sedimentation chambers, where pollutants are removed through sedimentation and filtration. Storm water is then conveyed from the sedimentation chambers to a surrounding constructed wetland. Unlike most constructed wetlands systems, STS conveys the storm water directly into the subsurface of the wetland and through the root zone. Pollutants are then removed through filtration, adsorption, and biochemical reactions. These processes occur at higher rates within the root zone, making STS more efficient in

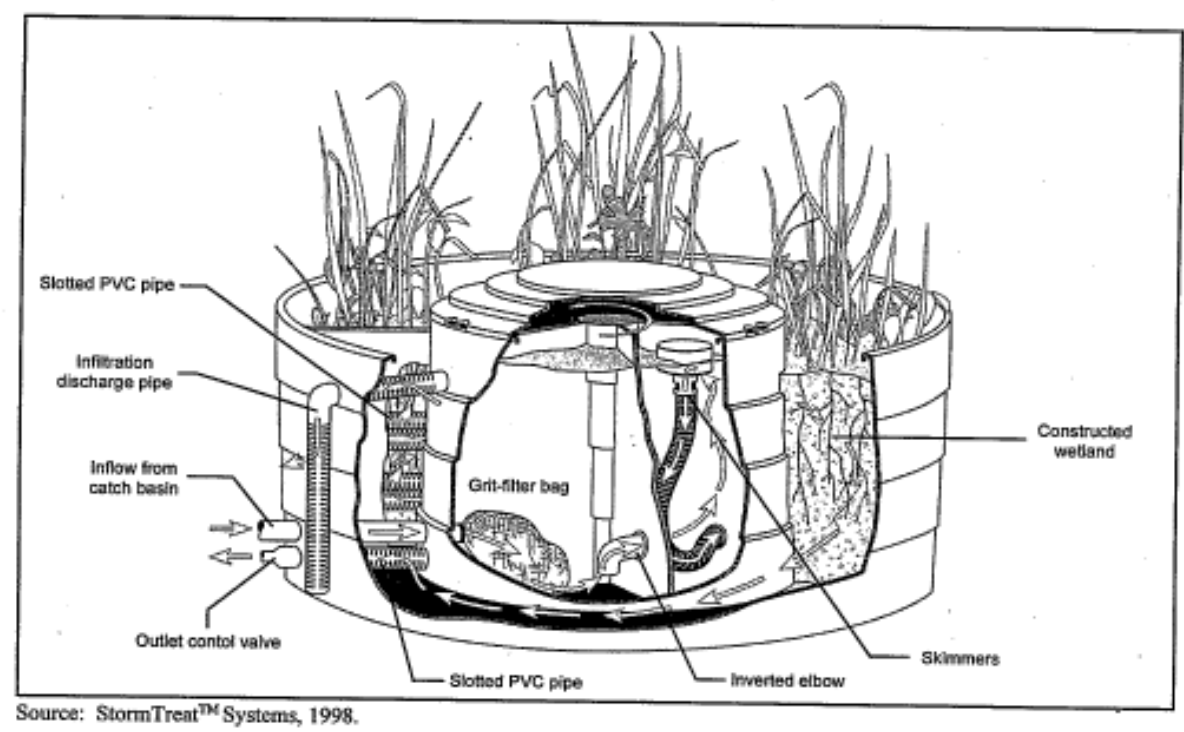

FIGURE 1 STORMTREAT TMSYSTEM 
WSRC-RP-2003-00276

page 50 of 53

pollutant removal. Storm water is retained in the wetlands for five to ten days prior to discharge.

The STS is suitable for use throughout the U.S.; however, the system may require modification to function in different environments. For example, as an option in dry climates such as in the southwestern U.S., STS has designed a solarpowered water pump to redirect water that is stored in the bottom of the system to the wetland plants. In addition, in arid regions such as these that do not have enough groundwater to support the wetland vegetation, the unit may be altered to release flow at a slower rate, thereby increasing the amount of water retained in the bottom of the unit; or it may be designed with soils that retain water more efficiently. Alternatively, the unit could have a backup water supply to provide for extended dry periods.

The STS design can be modified for areas with high groundwater levels or tidal influence. In areas with high groundwater, the discharge pipework can be modified so that runoff is discharged downgradient to an area with a lower water table. In tidallyinfluenced areas, a check valve can be installed to prevent flow from re-entering the unit at its discharge point. This will also allow discharge to be released only during mid- to low-tide conditions.

Over 100 STS units have been installed nationwide, including installations in California, Washington, Oregon, Oklahoma, North Carolina, South Carolina, Maryland, New York, Connecticut, New Hampshire, Maine, Rhode Island, and Massachusetts. An STS has been operating in Kingston, Massachusetts, since November 1994. This unit was installed to prevent bacterial contamination from storm runoff from harming shellfish beds in the Jones River. Additional systems have been recently installed in various parts of Massachusetts, as well as in Maine. In Hingham, MA, six STSs were installed in an industrial park bordering a wetland that is a tributary to a drinking water supply. These STSs have been successful in preventing contamination of the water supply. In Ipswich, MA, and Barnstable, MA, several STS tanks were installed to treat road and parking lot drainage to prevent discharges to sensitive receiving waters. Finally, in
Manchester, ME, five STSs were installed to help reduce the levels of phosphorus in storm water effluent after new regulations tightened runoff standards for phosphorous.

\section{APPLICABILITY}

The STS has applications in a wide range of settings. The system's size and modular configuration make it adaptable to a wide range of site constraints and watershed sizes. Designers of the system indicate that the system can be used to treat runoff from highways, parking lots, airports, marinas, and commercial, industrial, and residential areas. The STS is an appropriate storm water treatment technology for both coastal and inland areas but is not designed to be used directly in wastewater streams.

\section{ADVANTAGES AND DISADVANTAGES}

Regulators and environmental groups in Massachusetts are utilizing storm water management practices, including the STS, to improve water quality in the shellfish beds located downstream from potentially contaminated runoff. The STS also protects groundwater by removing pollutants prior to infiltration. The STS has shown high total petroleum hydrocarbons (TPH), Total Phosphorus (TP), metals, and suspended solids removal rates, which improves water quality. An additional benefit of the STS is the system's spill containment feature, which can capture an upstream release and therefore lessen the spill's impact on the environment. However, as previously discussed, the STS is relatively new and remains to be thoroughly tested in different geographical locations. There may be possible limitations in different areas, although soil types and high water tables surrounding the modular unit will not limit the system's effectiveness.

\section{DESIGN CRITERIA}

The STS is a modular, 2.9-meter (9.5-foot) diameter recycled-polyethylene tank containing a series of sedimentation chambers and constructed wetlands. The sedimentation chambers are in the inner ring of the tank, which has a diameter of nearly 1.7 -meters (5.5 feet). The 2.9-meter 
diameter outer ring, which surrounds the sedimentation chambers, contains the wetland. The tank walls and bulkheads, which separate the sedimentation chambers, are 1.2-meters (4 feet) high.

STS tanks are designed to withstand the weight of the saturated soils surrounding the tanks. Influent is conveyed from a catch basin (and other preliminary detention structures) through poly-vinyl chloride (PVC) piping to the first of six internal sedimentation chambers. A synthetic woven sack placed at the end of the 10 centimeter ( 4 inch) diameter inlet pipe traps large particles and debris. Skimmers floating on the water surface within each chamber convey flow to the following chamber through an opening 15 centimeters ( 6 inches) below the surface. This prevents sediment and floatables from being transported to the subsequent chamber. Sediments that collect in the bottom of the chamber remain there until the unit is cleaned. The bulkhead separating the last two sedimentation chambers is fitted with an inverted elbow, which traps oil and grease. The settling efficiency increases by transferring water from the top of each chamber to the subsequent chamber.

Flow is conveyed from the final sedimentation chamber through four, slotted PVC outlet pipes, each $10 \mathrm{~cm}$ (4 inches) in diameter, into the wetland portion of the STS. Partially treated storm water flows beneath the soil through the wetland. The wetland has an approximate storage capacity of 2,880 liters (760 gallons). The entire system has a static holding volume of 5,270 liters $(1,390$ gallons). However, the system is sized based upon this volume plus associated detention structures.

Vegetation within the wetland will vary depending on the local conditions (climatological). Bulrush and burreeds (which have maximum root depths of 0.8 and 0.6 meters (2.6 and 2 feet), respectively [U.S. EPA, 1993]) have been used in Massachusetts. Mature vegetation in the outer ring should have roots that extend into the permanent 15 $\mathrm{cm}$ (6 inches) of water in the bottom of the tank. Insufficient root depth may result in a lack of water supply to the plants during the periods between storm events.
Effluent from the wetland is discharged through a 5 centimeter ( 2 inch) diameter pipe that is controlled by a valve. Flow rates and holding times can be varied by manipulating the outlet control valve. At the Kingston facility, the control valve is adjusted to provide the recommended discharge rate of 0.1 liters per second ( 0.2 gallons per minute) and a five day holding time in the wetland. The valve has an added benefit that in the event of an upstream toxic spill, it can be closed, trapping the pollutants in the STS.

Tanks are available in one size, but several tanks can be installed at a site to capture the projected volume of runoff. The determination of the number of tanks needed for a site is based on three factors:

- Area of impervious drainage surfaces.

- Design storm to be treated.

- Detention storage prior to the STS tanks.

Generally 1-2 units are required for each acre of impervious surface. The system is sized based upon the design storm which is determined by state regulations (i.e., Maine requires treatment of first half inch of storm and Washington requires treatment of a six month storm). This first flush storage volume is stored in preliminary storage structures such as underground tanks and large diameter pipes (which can be place under parking areas).

\section{PERFORMANCE}

Runoff from the STS installed in Kingston, MA, was analyzed to assess pollutant removal efficiency. Thirty-three samples were collected over eight independent storm events during both winter and summer conditions. Sampling results are shown in Table 1. The results indicate removal rates of 97 percent for fecal coliform bacteria, 99 percent for total suspended solids, and 90 percent for total petroleum hydrocarbons. Nutrient removal rates were 82 percent chemical oxygen demand, 77 percent total dissolved nitrogen, and 90 percent phosphorus. Metal removal rates were 77 percent for lead, 98 percent for chromium, and 90 percent for zinc. 


\section{TABLE 1 STORMTREAT ${ }^{\text {TM }}$ SAMPLING RESULTS FOR KINGSTON, MA}

\begin{tabular}{lc}
\hline Pollutant & $\begin{array}{c}\text { Percent } \\
\text { Removed }\end{array}$ \\
\hline Fecal Coliform Bacteria & 97 \\
Total Suspended Solids & 99 \\
Chemical Oxygen Demand & 82 \\
Total Dissolved Nitrogen & 77 \\
Phosphorous & 90 \\
Total Petroleum Hydrocarbons & 90 \\
Lead & 77 \\
Chromium & 98 \\
Zinc & 90 \\
\hline \hline
\end{tabular}

Source: StormTreat ${ }^{\text {TM }}$ Systems, Inc., 1998.

In addition to the study in Kingston, MA, several other studies are currently being conducted in Connecticut, California, and Massachusetts. This data has not been fully developed and is not yet available.

\section{OPERATION AND MAINTENANCE}

Anticipated maintenance of the STS is minimal. The system should be observed at least once a year to be sure that it is operating effectively. At that time, the burlap sack that covers the influent line should be replaced. If the installed system uses filters, these should be removed, cleaned, and reinstalled. Sediment should be removed from the system once every three to five years, more often if the system has higher than normal sediment loads. The sediment level may be measured with a probe or even a yard stick. It is recommended that the sediment be removed when 0.3 meters ( 1 foot) of sediment has accumulated. After six months of operation the unit installed in Kingston, MA was found to have 5 centimeters (2 inches) of accumulated sediment. The sediment can be pumped from the tank by septic haulers or by maintenance personnel responsible for sediment removal from catch basins. It is not anticipated that the sediment will be toxic, and it may be safely landfilled. However, sediment toxicity will depend on the activities in the contributing drainage area and testing of the sediment may be required to determine if it is considered hazardous. Because the STS system is relatively new, there is no definitive data on the lifetime of the plants and gravel in the system. However, it is estimated that these will need to be replaced every 10 to 20 years.

\section{Costs}

The STS is a prefabricated unit that is easily installed in most locations. The cost for one unit is $\$ 4,900$, and the installation cost is usually between $\$ 500$ and $\$ 1,000$ (which is provided by the manufacture). Additional materials required include gravel, PVC piping, and wetland plants, at a total cost of about $\$ 350$ to $\$ 400$ per tank. Capital and installation costs per tank decrease as the number of units on a site increases. Installation will cost less if construction on that site is new (not retrofitted) because drainage lines will be more easily accessible. Installation will cost more if there are extra construction costs (for example, retrofit design) or if there are complications. StormTreat ${ }^{\mathrm{MM}}$ Systems recommends one STS unit per one acre of impervious surface.

The estimated maintenance cost for removal of sediment from one tank ranges from $\$ 80$ to $\$ 120$. This cost is incurred every three to five years, when sediment is removed. Costs have not been determined for an annual site inspection or for removing any debris from the wetland area. However, these costs should be minimal (i.e., one day of labor for one person per year).

\section{REFERENCES}

1. Horsley, S. W. and W. Platz, 1995. Progress Report: Water Quality Monitoring at Elm Street Facility. Barnstable, Massachusetts (relocated to Hyannis, MA).

2. Horsley, S. W., 1995. The StormTreat ${ }^{2 M}$ System - A New Technology for Treating Storm Water. 
3. Horsley, S. W., 1998, Personal communication with Parsons Engineering Science, Inc.

4. Horsley \& Witten, Inc., 1998. Fact Sheet - Modeling of Water Flow Through the StormTreat ${ }^{\text {TM }}$ System.

5. Oregon Department of Environmental Quality, 1998. Storm Water Management Guidelines. Internet site at [http://waterquality.deq.state.or.us/wq/gro undwa/swmgtguide.htm], accessed February, 1998.

6. StormTreat Systems, Inc., 1998. StormTreat ${ }^{\mathrm{TM}}$ Systems Newsletter. Barnstable, Massachusetts (relocated to Hyannis, MA).

7. StormTreat Systems, Inc., Undated. Technical Data for StormTreat ${ }^{\mathrm{TM}}$ System. Barnstable, Massachusetts (relocated to Hyannis, MA).

8. U.S. EPA, 1993. Subsurface Flow Constructed Wetlands for Wastewater Treatment: A Technology Assessment. EPA 832-R-93-001.

\section{ADDITIONAL INFORMATION}

Ecocycle

George Lord

P.O. Box 228

Manchester, ME 04351

Land Use Consultants, Inc.

Pat Clark

966 Riverside Street

Portland, ME 04103

New Hampshire Department of Environmental Services

Steve Landry

6 Hazen Drive

Concord, NH 03302
Storm Treat ${ }^{\mathrm{TM}}$ Systems, Inc.

Scott Horsley

90 Route 6A, Sextant Hill

Sandwich, MA 02563

University of Washington

Chris May

Applied Physics Laboratory

UW Box 355640

Seattle, WA 98105

The mention of trade names or commercial products does not constitute endorsement or recommendation for the use by the U.S. Environmental Protection Agency.
For more information contact:

Municipal Technology Branch U.S. EPA

Mail Code 4204

401 M St., S.W. 